\title{
INTERDISCIPLINARY (MINERALOGICAL-GEOLOGICAL- ARCHAEOLOGICAL) STUDY ON THE TEGULAR MATERIAL BELONGING TO THE LEGION XIII GEMINA FROM ALBURNUS MAIOR (ROŞIA MONTANĂ) AND APULUM (ALBA IULIA): POSSIBLE RAW MATERIALS SOURCES
}

\author{
Corina Ionescu, Lucreția Ghergari, Ovidiu Țentea
}

\begin{abstract}
From a high number of bricks and tiles found at Alburnus Maior (Roşia Montană) and Apulum (Alba Iulia) (Romania), twenty two fragments were studied. The ceramics consists mainly of a matrix with crystalline and/or amorphous fabric, showing different degrees of sinterization and vitrification. In the matrix variable amounts of magmatic, metamorphic and sedimentary lithoclasts, various crystalloclasts (quartz, feldspar, mica), and rare ceramoclasts and bioclasts are present. Regarding the grain size, the ceramics is mainly lutitic-siltic-arenitic, with a contribution of arenaceous-sized grains exceeding $15 \%$ and reflecting the coarse category for all samples. The composition of the lithoclasts and crystalloclasts indicates that quartz sands were used as temper materials for the ceramics. Quartzite, granite-granodiorite, basalt, andesite/basaltic andesite, gneiss and limestone are ubiquitous lithoclasts.

Microscopical observations on the matrix as well as the X-ray diffraction indicate the use of polymictic clays, consisting mainly of illite, kaolinite \pm smectite \pm calcite \pm micas as raw materials. The clays seem to be similar for both, the Roşia Montană and the Alba Iulia artefacts.

The firing temperatures were inferred from both, the thermal changes of primary minerals such as the fissuring of quartz, the decomposition of calcite, the contraction holes around some lithoclasts, the change of the anisotropy of clay minerals, and the forming of melt-glass, gehlenite, wollastonite and hematite, and the disappearance of some lines of clay minerals, the presence of hematite, gehlenite and wollastonite lines, the modification of calcite lines in X-Ray diffractograms. Based on the firing temperatures, the ceramic artefacts were classified in three categories:

- Type I ceramics, fired at lowest temperature $\left(800-850^{\circ} \mathrm{C}\right)$;

- Type II ceramics, fired at $850-900^{\circ} \mathrm{C}$;

- Type III ceramics, fired at $900-950^{\circ} \mathrm{C}$.

In the Alba Iulia site well-fired ceramics are prevalent $\left(850-950^{\circ} \mathrm{C}\right)$, while the Roşia Montană ceramics are mainly fired at lower temperatures $\left(800-900^{\circ} \mathrm{C}\right)$.

Being based on the mineral composition of the matrix (illite, kaolinite \pm smectite \pm calcite + mica), we presume that clays with an according composition, outcropping west of Sântimbru, east of Şard and west of Alba Iulia were used as raw materials.

The mineralogical and petrographical composition of the crystalloclasts and lithoclasts respectively, in the ceramics both from Roşia Montană and Alba Iulia is similar. Granites and granodiorites are similar to those crossed by the Arieş river, north of Alba Iulia, basalts, basaltic andesites, radiolarites are surely originated from the Mesozoic ophiolitic zone outcropping westwards of Alba Iulia and limestones outcrop westwards of Alba Iulia, together with the ophiolites.These lithoclasts are also found in the alluvial sediments of the Mureş river downstream the confluence with the Ampoiu river. Thus, we presume that the temper was most likely mined from the right bank of the Mureş river, south-east of Alba Iulia. Even today this location provides quartz sands, used for bricks and tiles manufacture.
\end{abstract}

Keywords: brick stamps, samples, mineralogica land petrographical analysis 


\section{INTRODUCTION}

This study completes the archaeological research carried out both on the tegular material belonging to the Legion XIII Gemina, recently discovered at Roşia Montană (Alburnus Maior) and on some samples -typologic analogiesfrom the Alba Iulia (Apulum) site (Fig. 1). In the followings, the previous historical-
During the 2001-2003 archaeological campaign in Roşia Montană (Alburnus Maior), two buildings (E1 and E2) dated from the beginning of the second century A.D. were found on the Carpeni Hill. A large quantity of exhumed artefacts represents tegular material marked with the Legion XIII Gemina ${ }^{3}$ stamp, the occurrence of these tegular stamps at

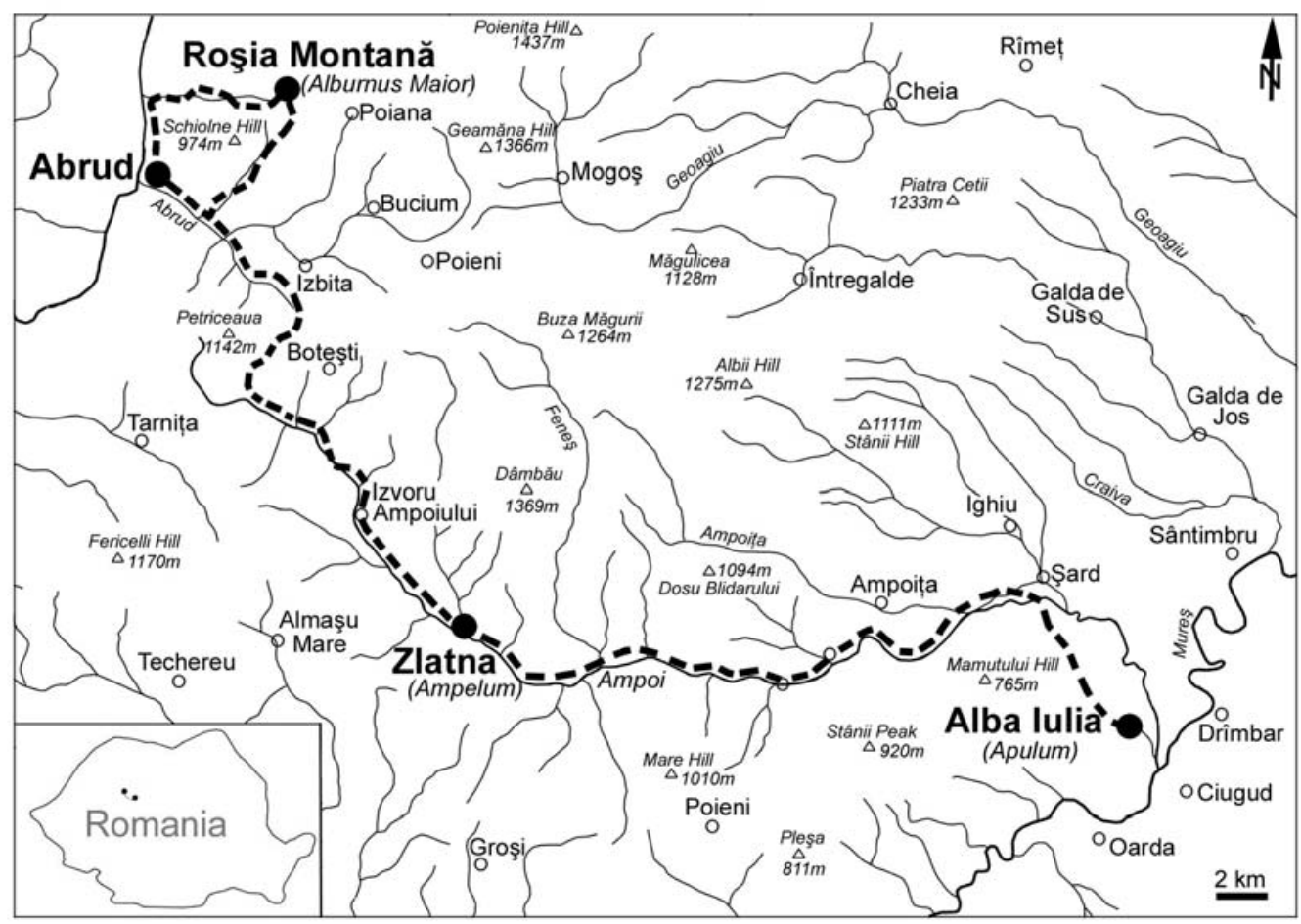

- The actual road between Alba lulia and Roşia Montană (about 75 kms).

Fig. 1. The location of Roşia Montană (Alburnus Maior) and Alba Iulia (Apulum) on the Romania map.

archaeological considerations will be completed by mineralogical-petrographical analyses. It has to be mentioned, from the beginning, that the most of the interdisciplinary studies are performed mainly by specialists asked by the archaeologists to analyse some artefacts. For the archaeologist, these studies have a „technical” character" which demands a latter „decoding", in spite to evaluate the parameters of the historical reconstitutioning. We tried to make understandable the results of this study for the archaeologists, and some mineralogicalpetrographical-geological terms will be shortly explained in the glossary or in the footnotes ${ }^{2}$.

\footnotetext{
${ }^{1}$ For a short presentation and some references see also Țentea 2003a, 115-116.

${ }^{2}$ An interdisciplinary study published years ago, included only footnotes explanations of some terms (Ghergari et al. 2000).
}

Alburnus Maior being related with the defence of the gold-mining area by the Roman army. If some vexilations of the legion were present at Alburnus Maior or if the workshop for the tegular material was at Apulum (the location of the legion garrison) or at Alburnus Maior, these are two hypotheses argued so far by different authors ${ }^{4}$ mostly based on the ,historical logic”.

\footnotetext{
${ }^{3}$ The constructions were labelled E1 and E2; see Bota et al. 2003, 435-437 and Țentea, Voişian 2003, 449-451.

4 As no epigraphs documented the presence of the legion at Alburnus Maior, the discussions were focused mainly on the tegular stamps: see also Țentea 2003, who supposed a low probability for the transporting of large quantities of tegular material from Apulum to Alburnus Maior, based on the high expenses required. For the trace of the Apulum - Ampelum - Alburnus Maior Roman road see Wollmann 1996, pl. LXVI.
} 
TABLE 1.

\section{ARCHAEOLOGICAL CONTEXT AND MACROSCOPICAL DESCRIPTION OF THE TEGULAR SAMPLES FROM ROŞIA MONTANĂ (RM)}

\begin{tabular}{|c|c|c|}
\hline Sample no. & Archaeological context & Macroscopical characteristics \\
\hline 79-1RM & $\begin{array}{l}\text { E1 } 2001 \text { - Bota, Țentea, Voişian } \\
\text { 2003, } 444 \text { fig. } 8 / 1=\text { Țentea } 2003 \\
\text { 264 Fig. } 2 / 1\end{array}$ & $\begin{array}{l}\text { - Light red-yellowish, homogeneous colour } \\
\text { - Heterogeneous composition of the matrix } \\
\text { - Two ranges of clasts, below } 1 \mathrm{~mm} \text { and larger, up to } 3-4 \mathrm{~mm} \text { diametre } \\
\text { - Rare, elongated-shaped pores of } 0.1 \times 3 \mathrm{~mm} \text { in size }\end{array}$ \\
\hline $79-2 \mathrm{RM}$ & $\begin{array}{l}\text { E1 } 2001 \text { - Bota, Țentea, Voişian } \\
\text { 2003, } 444 \text { fig. } 8 / 2=\text { Țentea } 2003 \text {, } \\
\text { 264 Fig. } 2 / 2 \text { ) }\end{array}$ & $\begin{array}{l}\text { - Unhomogeneous aspect: red-yellowish background colour with } \\
\text { creamy or greyish spots (clasts) } \\
\text { - Unhomogeneous composition of the matrix: mixture of clasts-bearing } \\
\text { zones and clasts-free zones } \\
\text { - Two categories of clasts: large }(2-3 \text {, sometimes } 5 \mathrm{~mm}) \text { and small (0.1- } \\
\quad 0.2 \mathrm{~mm}) \\
\text { - Some clasts (the calcitic ones) are highly friable } \\
\text { - Rare pores, of small size (below } 0.6 \mathrm{~mm})\end{array}$ \\
\hline 79-3RM & $\begin{array}{l}\text { E1 2001 - Bota, Țentea, Voişian } \\
\text { 2003, } 444 \text { Fig. } 8 / 3=\text { Țentea } 2003 \text {, } \\
\text { 264 Fig. } 2 / 3\end{array}$ & $\begin{array}{l}\text { - Light red-yellowish, homogeneous colour } \\
\text { - Heterogeneous composition of the matrix } \\
\text { - Two categories of clasts: large (up to } 3-4 \mathrm{~mm} \text { ) and small (below } 1 \\
\text { mm) } \\
\text { - Rare, elongated pores of } 0.1 \times 3 \mathrm{~mm} \text { in size }\end{array}$ \\
\hline 79-4RM & $\begin{array}{l}\text { E1 2001 - Bota, Țentea, Voişian } \\
\text { 2003, } 444 \text { Fig. } 8 / 4 a, 4 b=\text { T,entea } \\
\text { 2003, } 264 \text { fig. } 2 / 4 a, 4 b\end{array}$ & $\begin{array}{l}\text { - Light red-yellowish, homogeneous colour } \\
\text { - Homogeneous composition of the matrix } \\
\text { - Two categories of clasts: large (up to } 2-3 \mathrm{~mm} \text { ) and small (below } 1 \\
\text { mm) } \\
\text { - Rare, elongated pores, of } 0.1 \times 3 \mathrm{~mm} \text { in size }\end{array}$ \\
\hline 79-5RM & $\begin{array}{l}\text { E2 } 2001 \text { - Ţentea, Voişian } 2003, \\
\text { 452 Fig. } 15 / 1=\text { Țentea } 2003,265 \\
\text { Fig. } 3 / 5\end{array}$ & $\begin{array}{l}\text { - Light red-yellowish, homogeneous colour } \\
\text { - Homogeneous composition of the matrix } \\
\text { - Rare clasts, smaller than } 1 \mathrm{~mm} \text { diametre } \\
\text { - Rare, elongated pores of } 0.1 \times 3 \mathrm{~mm} \text { in size }\end{array}$ \\
\hline 79-6RM & $\begin{array}{l}\text { E2 } 2001-\text { Ţentea, Voişian } 2003, \\
\text { 452 Fig. } 15 / 2=\text { Țentea } 2003,265 \\
\text { Fig. } 3 / 6\end{array}$ & $\begin{array}{l}\text { - Light red-yellowish, homogeneous colour } \\
\text { - Heterogeneous composition of the matrix } \\
\text { - Creamy-coloured clasts, of two sizes: either below } 1 \mathrm{~mm} \text { or larger, up } \\
\text { to } 3-4 \mathrm{~mm} \\
\text { - Rare, elongated pores of } 0.1 \times 3 \mathrm{~mm} \text { in size }\end{array}$ \\
\hline 79-7RM & $\begin{array}{l}\text { E2 } 2001-\text { Țentea, Voişian } 2003, \\
\text { 452 Fig. } 15 / 3=\text { Țentea } 2003,265 \\
\text { Fig. } 3 / 7\end{array}$ & $\begin{array}{l}\text { - Unhomogeneous aspect: red-yellowish background colour with white, } \\
\text { creamy or greyish spots (clasts) } \\
\text { - Homogeneous composition of the matrix, light stratification } \\
\text { - Clasts of various sizes, from } 0.2 \text { up to } 2 \mathrm{~mm} \\
\text { - Rare, elongated small }(<0.6 \mathrm{~mm}) \text { pores }\end{array}$ \\
\hline 79-8RM & $\begin{array}{l}\text { E2 } 2001 \text { - Țentea, Voişian } 2003, \\
\text { 452 Fig. } 15 / 4=\text { Țentea 2003, } 265 \\
\text { Fig. } 3 / 8\end{array}$ & $\begin{array}{l}\text { - Brownish red, homogeneous colour } \\
\text { - Homogeneous composition of the matrix } \\
\text { - Rare clasts, smaller than } 0.3 \mathrm{~mm} \\
\text { - Rare, elongated pores, of } 0.1 \times 3 \mathrm{~mm} \text { in size }\end{array}$ \\
\hline 79-9RM & $\begin{array}{l}\text { E } 22002 \text { - inedit (vezi date } \\
\text { arheologice - Voişian, Țentea 2004, } \\
\text { 281) }\end{array}$ & $\begin{array}{l}\text { - Unhomogeneous aspect: red-yellowish background colour with white, } \\
\text { creamy or greyish spots (clasts) } \\
\text { - Heterogeneous composition of the matrix, mixture of large clasts- } \\
\text { bearing zones and clasts-free zones. } \\
\text { - Two categories of clasts: large clasts (up to } 2-3 \mathrm{~mm} \text {, sometimes } 5 \mathrm{~mm} \text { ) } \\
\text { and small clasts }(0.1-0.2 \mathrm{~mm}) \\
\text { - Some clasts (the calcitic ones) are friable } \\
\text { - Rare, small pores }(<0.6 \mathrm{~mm})\end{array}$ \\
\hline 79-10RM & $\begin{array}{l}\text { E } 22002 \text { - inedit (vezi date } \\
\text { arheologice - Voişian, Țentea 2004, } \\
\text { 281) }\end{array}$ & $\begin{array}{l}\text { - Unhomogeneous aspect: red-yellowish background colour with white, } \\
\text { creamy or greyish spots (clasts) } \\
\text { - Heterogeneous composition of the matrix } \\
\text { - Numerous clasts, from } 0.2 \text { to } 2 \mathrm{~mm} \text { in diametre } \\
\text { - Rare, elongated small pores }(<0.6 \mathrm{~mm}) \text {; some pores contain secondary } \\
\text { calcite }\end{array}$ \\
\hline 79-11RM & $\begin{array}{l}\text { E } 22002 \text { - inedit (vezi date } \\
\text { arheologice - Voişian, Țentea 2004, } \\
\text { 281) }\end{array}$ & $\begin{array}{l}\text { - Unhomogeneous aspect: red-yellowish background colour with } \\
\text { creamy spots (clasts) } \\
\text { - Homogeneous composition of the matrix } \\
\text { - Clasts of } 0.1 \text { to } 3 \mathrm{~mm} \text { in size } \\
\text { - Rare, small irregular-shaped pores }(<0.5 \mathrm{~mm})\end{array}$ \\
\hline 79-12RM & $\begin{array}{l}\text { E } 22002 \text { - inedit (vezi date } \\
\text { arheologice - Voişian, Țentea 2004, } \\
\text { 281) }\end{array}$ & $\begin{array}{l}\text { - Red, homogeneous colour } \\
\text { - Homogeneous composition of the matrix } \\
\text { - Rare clasts, smaller than } 0.1 \mathrm{~mm} \\
\text { - Rare, small pores }(<0.1 \mathrm{~mm})\end{array}$ \\
\hline
\end{tabular}


TABLE 2.

ARCHAEOLOGICAL CONTEXT AND MACROSCOPICAL DESCRIPTION OF THE TEGULAR SAMPLES FROM ALBA IULIA

\begin{tabular}{|c|c|c|}
\hline Sample no. & Archaeological context & Macroscopical characteristics \\
\hline 79-14AI & $\begin{array}{l}\text { Apulum I Partoş - IDR III/6, } 6 \\
\text { (LEG XIII) }\end{array}$ & $\begin{array}{l}\text { - Light red, homogeneous colour } \\
\text { - Homogeneous composition of the matrix } \\
\text { - Rare clasts, smaller than } 0.5 \mathrm{~mm} \\
\text { - Numerous elongated pores of } 0.1 \times 6 \text { to } 0.2 \times 10 \mathrm{~mm}\end{array}$ \\
\hline $79-15 \mathrm{AI}$ & $\begin{array}{l}\text { Apulum I Partoş - IDR III/6, } 36 \\
\text { (LEG XIII) }\end{array}$ & $\begin{array}{l}\text { - Light red, homogeneous colour } \\
\text { - Homogeneous composition of the matrix } \\
\text { - Rare clasts, smaller than } 0.2 \mathrm{~mm} \\
\text { - Rare, rounded pores of } 0.2 \mathrm{~mm} \text { in diametre }\end{array}$ \\
\hline 79-16AI & Apulum castru - IDR III/6, 45 & $\begin{array}{l}\text { - Unhomogeneous aspect: intense red-orange background colour with } \\
\text { white, creamy or greyish spots (clasts) } \\
\text { - Homogeneous composition of the matrix; obvious stratification } \\
\text { - Two categories of clasts: a large clasts (up to } 2-3 \mathrm{~mm} \text { ) and small clasts } \\
\quad(0.2 \mathrm{~mm}) \\
\text { - Numerous elongated pores of } 0.2 \times 1 \text { to } 0.8 \times 8 \mathrm{~mm} \text { in size }\end{array}$ \\
\hline $79-17 \mathrm{AI}$ & $\begin{array}{l}\text { Apulum Pretoriul guvernatorului - } \\
\text { IDR III/6, } 72 \text { (LEG XIII) }\end{array}$ & $\begin{array}{l}\text { - Unhomogeneous aspect: light red-orange background colour with } \\
\text { creamy or greyish spots (clasts) } \\
\text { - Homogeneous composition of the matrix; light stratification } \\
\text { - Numerous clasts, larger than } 0.5 \mathrm{~mm} \text { in diametre } \\
\text { - No pores }\end{array}$ \\
\hline $79-18 \mathrm{AI}$ & $\begin{array}{l}\text { Apulum II - IDR III/6, } 85 \text { (LEG } \\
\text { XIII) }\end{array}$ & $\begin{array}{l}\text { - Light red, homogeneous colour } \\
\text { - Homogeneous composition of the matrix } \\
\text { - Rare clasts, smaller than } 1 \mathrm{~mm} \\
\text { - Elongated pores from } 0.3 \times 3 \mathrm{~mm} \text { up to } 3 \times 3 \mathrm{~mm} \text { in size }\end{array}$ \\
\hline 79-19AI & $\begin{array}{l}\text { Apulum I Partoş - IDR III/6, } 438 \\
\text { (LEG XIII) }\end{array}$ & $\begin{array}{l}\text { - Unhomogeneous aspect: dark red background colour with white, } \\
\text { creamy or greyish spots (clasts) } \\
\text { - Homogeneous composition of the matrix; obvious stratification } \\
\text { - Frequent clasts, larger than } 0.5 \mathrm{~mm} \text { up to } 3 \mathrm{~mm} \text { in diametre } \\
\text { - Rare, elongated pores of } 0.4 \text { x } 2 \text { to } 1 \text { x } 5 \mathrm{~mm} \text { size }\end{array}$ \\
\hline $79-20 \mathrm{AI}$ & $\begin{array}{l}\text { Apulum I Partoş - IDR III/6, } 289 \\
\text { (tegulae privatae) }\end{array}$ & $\begin{array}{l}\text { - Unhomogeneous aspect: dark red background colour with white, } \\
\text { creamy or greyish spots (clasts) } \\
\text { - Homogeneous composition of the matrix; obvious stratification due to } \\
\text { the modeling } \\
\text { - Numerous clasts, of } 0.5 \text { to } 3 \mathrm{~mm} \text { diametre } \\
\text { - Rare, elongated pores of } 0.4 \times 2 \text { to } 1 \times 5 \mathrm{~mm} \text { in size }\end{array}$ \\
\hline $79-21 \mathrm{AI}$ & $\begin{array}{l}\text { Apulum I Partoş - IDR III/6, } 293 \\
\text { (tegulae privatae) }\end{array}$ & $\begin{array}{l}\text { - Light red-orange, homogeneous colour } \\
\text { - Homogeneous composition of the matrix } \\
\text { - Very rare clasts, about } 0.3 \mathrm{~mm} \text { diametre } \\
\text { - Rare, elongated pores of } 0.2 \times 4 \mathrm{~mm} \text { in size }\end{array}$ \\
\hline $79-22 \mathrm{AI}$ & $\begin{array}{l}\text { Apulum I Partoş - IDR III/6, } 298 \\
\text { (tegulae privatae) }\end{array}$ & $\begin{array}{l}\text { - Unhomogeneous aspect: dark red background colour with white, } \\
\text { creamy or greyish spots (clasts) } \\
\text { - Homogeneous composition of the matrix; obvious stratification } \\
\text { - Two categories of clasts: mainly small clasts }(0.2-1 \mathrm{~mm}) \text {, large clasts } \\
\text { (up to } 2-6 \mathrm{~mm} \text { ) are rare } \\
\text { - Numerous pores, either rounded (gas bubbles?) of } 0.3-1 \mathrm{~mm} \\
\text { diametre, or elongated-shaped of } 0.2 \times 4 \mathrm{~mm} \text { diametre }\end{array}$ \\
\hline $79-23 \mathrm{AI}$ & $\begin{array}{l}\text { Apulum I Partoş - IDR III/6, } 445 \\
\text { (tegulae privatae) }\end{array}$ & $\begin{array}{l}\text { - Light red, homogeneous colour } \\
\text { - Homogeneous composition of the matrix } \\
\text { - Frequent clasts, mainly small }(0.1-0.2 \mathrm{~mm}) \text { larger clasts }(2 \mathrm{~mm}) \text { are } \\
\quad \text { rare } \\
\text { - Numerous elongated pores, uneven distributed in the matrix }\end{array}$ \\
\hline
\end{tabular}


The main aim of the mineralogicalpetrographical-geological analyses on the tegular material was to outline the provenance area for both, the raw clays and the temper sources. Twelve samples were taken from artefacts marked with the legion stamp, found during the recent archaeological research from Roşia Montană ${ }^{5}$. They have been compared, from mineralogical-petrographical-geological point of view, with ten samples of tegular material belonging to same legion and found at Apulum. To compare materials belonging to the same chronological segment, the Apulum samples marked with similar types of stamps as those from the Alburnus Maior, were selected.

\section{SAMPLES AND METHODS}

From a high number of exhumed Roman tegular ceramics (bricks and tiles), twenty two fragments were studied (tables 1, 2), 12 from Alburnus Maior (Roşia Montană) (labelled 79$1 \mathrm{RM}$ to $79-12 \mathrm{RM}$ ) and 10 from Apulum (Alba Iulia) (labelled 79-14AI to 79-23AI) ${ }^{6}$. The samples were washed with distilled water and dried at room temperature for several days. The macroscopical observations, with naked eye or with Nikon SMZ660 stereoscopic microscope, allowed the identification of some features of the ceramics, in fresh break. From each sample, thin sections were made by cutting slices of 2 to $3 \mathrm{~mm}$ thickness, with a diamond saw blade. These ceramic slices were fixed on a glass lamella and polished up to a final $0.02 \mathrm{~mm}$ thickness. The thin sections were mineralogically and petrographically studied with a Nikon Eclipse E200 Pol microscope using plan polarized light, for mineral phases and thermal changes identification. The microscopic photos were obtained with a Nikon COOLPIX 995 digital camera. The mineralogical and petrographical study was completed with X-Ray powder diffractions (Ghergari, Ionescu 2000). Few grams from each sample were hand milled in an agate mortar, then exposed to X-rays in a Dron-3 diffractometer with $\mathrm{Cu}$ anticathode, $\mathrm{K}_{\alpha}$

\footnotetext{
${ }^{5}$ In this analysis we included also four samples found in the 2002 campaign. See Voişian, Țentea 2004, 281.

${ }^{6}$ Each sample has a 79 number, assigned to the Applied Mineralogy and Gemology Lab of the Mineralogy Chair (Babeş-Bolyai University of Cluj-Napoca).
}

radiation with $\lambda=1.54051 \AA$. The diffraction analyses allowed the identification of crystallized mineral compounds and the thermal changes due to the firing of ceramics.

The study of the tegular samples was focussed towards the microscopical characterization in order to create a database useful for future comparisons and analogies. The data obtained by various methods supported hypothesis regarding the type of raw materials, their geological sources, the processing technology and the location of the production centre.

\section{GRANULOMETRY AND FINENESS OF THE TEGULAR MATERIAL}

The granulometric measurements were performed on thin sections, at the petrographic microscope. The size and distribution of mineral compounds (matrix on one side, clasts on the other side) allowed the separation of granulometric categories as: lutite (particles with $<0.004 \mathrm{~mm}$ diametre), silt (particles with diametre between 0.063 and $0.004 \mathrm{~mm}$ ), arenite (particles with diametre between 2 and 0.063 $\mathrm{mm}$ ) and rudite (particles with $>2 \mathrm{~mm}$ diametre) (table 3). Both Roşia Montană and Alba Iulia tegular material belong to the lutiticsiltic-arenitic type. The projection of the measurements (table 3 ) in the L-AR-S ternary diagram (Fig. 2 ) $^{7}$ reveals the coarse character of the ceramics.

In average, the lutitic particles reprezent $\sim 52 \%$ in the ceramic mass in Roşia Montană samples and $\sim 53 \%$ in Alba Iulia samples. The siltic category is $28 \%$ in the Roşia Montană and $26 \%$ in the Alba Iulia, while arenite ranges up to $18 \%$ in the Roşia Montană and almost $20 \%$ in the Alba Iulia samples. The participation of the rudite category is very low, as $\sim 1 \%$ in the Roşia Montană and only $0.5 \%$ in the Alba Iulia samples.

\footnotetext{
${ }^{7}$ Acc. to the ancient ceramics classifications proposed by Ghergari et al. 1999; Ionescu, Ghergari 2002; Ionescu, Ghergari 2004, in: fine ceramics (arenite + rudite $<5 \%$ ), semifine ceramics (arenite + rudite between 5 and $15 \%$ ) and coarse ceramics (arenite + rudite $>15 \%$ ).
} 
TABLE 3.

GRANULOMETRY AND FINENESS OF THE TEGULAR CERAMICS FROM ROŞIA MONTANĂ (RM) AND ALBA IULIA (AI)

\begin{tabular}{|c|c|c|c|c|c|c|}
\hline \multirow[t]{2}{*}{ Sample no. } & \multicolumn{4}{|c|}{ Granulometric categories } & \multirow{2}{*}{$\begin{array}{l}\text { Whole ceramic body } \\
\text { granulometry }\end{array}$} & \multirow{2}{*}{$\begin{array}{c}\text { The fineness of } \\
\text { ceramics }\end{array}$} \\
\hline & $\begin{array}{c}\text { Lutite } \\
(\%)\end{array}$ & $\begin{array}{l}\text { Silt } \\
(\%)\end{array}$ & $\begin{array}{c}\text { Arenite } \\
(\%)\end{array}$ & $\begin{array}{c}\text { Rudite } \\
(\%)\end{array}$ & & \\
\hline 79-1RM & 54 & 28 & 18 & - & Lutitic-siltic-arenitic & coarse \\
\hline $79-2 \mathrm{RM}$ & 52 & 30 & 13 & 5 & Lutitic-siltic-arenitic & coarse \\
\hline 79-3RM & 51 & 30 & 19 & - & Lutitic-siltic-arenitic & coarse \\
\hline 79-4RM & 55 & 27 & 18 & - & Lutitic-siltic-arenitic & coarse \\
\hline 79-5RM & 49 & 30 & 21 & - & Lutitic-siltic-arenitic & coarse \\
\hline 79-6RM & 52 & 30 & 18 & - & Lutitic-siltic-arenitic & coarse \\
\hline 79-7RM & 51 & 28 & 18 & 3 & Lutitic-siltic-arenitic & coarse \\
\hline 79-8RM & 55 & 25 & 20 & - & Lutitic-siltic-arenitic & coarse \\
\hline 79-9RM & 55 & 28 & 17 & - & Lutitic-siltic-arenitic & coarse \\
\hline 79-10RM & 48 & 32 & 18 & 2 & Lutitic-siltic-arenitic & coarse \\
\hline 79-11RM & 52 & 28 & 20 & - & Lutitic-siltic-arenitic & coarse \\
\hline 79-12RM & 55 & 20 & 20 & 5 & Lutitic-siltic-arenitic & coarse \\
\hline Average & 52.42 & 28.00 & 18.33 & 1.25 & Lutitic-siltic-arenitic & coarse \\
\hline $79-14 \mathrm{AI}$ & 55 & 25 & 20 & - & Lutitic-siltic-arenitic & coarse \\
\hline $79-15 \mathrm{AI}$ & 50 & 30 & 20 & - & Lutitic-siltic-arenitic & coarse \\
\hline $79-16 \mathrm{AI}$ & 56 & 29 & 14 & 1 & Lutitic-siltic-arenitic & coarse \\
\hline $79-17 \mathrm{AI}$ & 53 & 30 & 17 & - & Lutitic-siltic-arenitic & coarse \\
\hline $79-18 \mathrm{AI}$ & 52 & 20 & 26 & 2 & Lutitic-siltic-arenitic & coarse \\
\hline 79-19AI & 52 & 30 & 18 & - & Lutitic-siltic-arenitic & coarse \\
\hline $79-20 \mathrm{AI}$ & 52 & 31 & 15 & 2 & Lutitic-siltic-arenitic & coarse \\
\hline $79-21 \mathrm{AI}$ & 54 & 20 & 26 & - & Lutitic-siltic-arenitic & coarse \\
\hline $79-22 \mathrm{AI}$ & 52 & 28 & 20 & - & Lutitic-siltic-arenitic & coarse \\
\hline $79-23 \mathrm{AI}$ & 58 & 22 & 20 & - & Lutitic-siltic-arenitic & coarse \\
\hline Average & 53.40 & 26.50 & 19.60 & 0.50 & Lutitic-siltic-arenitic & coarse \\
\hline
\end{tabular}

L: $100 \%$

I - The field of the fine ceramics

II - The field of the semifine ceramics

III - The filed of the coarse ceramics

O - Alba Iulia samples

- Roşia Montană samples

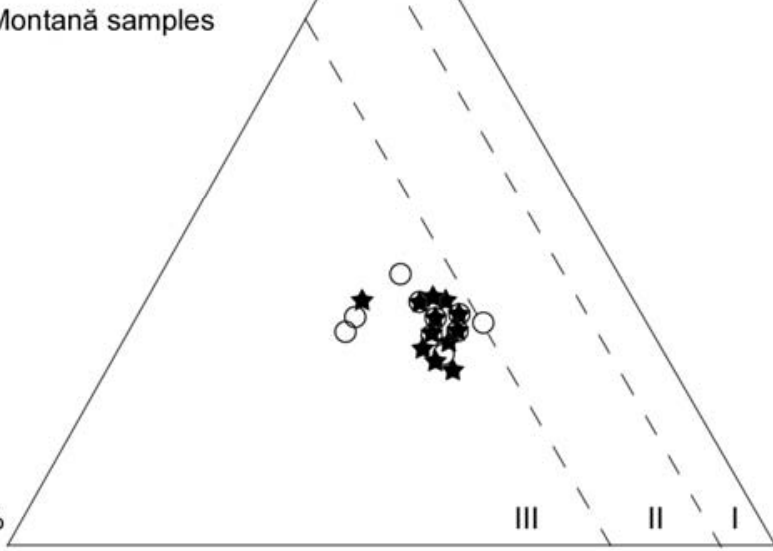

S: $70 \%$

L: $30 \%$

L: $30 \%$

Fig. 2. The projection of granulometric measurements in the $L($ utite $)-S($ ilt $)-A($ renite $)+R($ udite $)$ ternary diagram. 


\section{THE MINERALOGICAL AND PETROGRAPHICAL COMPOSITION OF THE TEGULAR CERAMICS}

\subsection{Macroscopical studies}

Macroscopically, the samples have a general reddish, homogeneous colour. The light-coloured spots of some samples are due to the clasts $^{8}$ (tables 1,2). The porosity is in general low and variable. The primary pores occur as elongate holes, arranged parallel with the brick surface, which are due to the modeling-pressing processes, such as air or/and water pockets left in between the clay fine laminae. The irregular holes, more or less isometrical, are secondary pores, resulted by thermal decomposition of some minerals (e.g. calcite) during the firing. The contaction holes occurred around some clasts are secondary pores as well.

\subsection{Polarized light microscopy}

The microscopical studies revealed the mineralogical and petrographical composition of the bricks and tiles as well as the thermal changes due to the firing. The ceramics is constituted from plastic (clayish matrix) and nonplastic (fragments of rocks, crystalls, potsherds) materials. The nonplastic materials originate from the raw clays, such as low quantities of quartz, micas, feldspar, calcite siltic grains, and from the temper added for controlling the plasticity of the ceramic mixture.

\section{The clayish matrix}

Microscopically, the ceramic matrix is constituted by very fine lamellar crystals of clay minerals, more or less thermally altered, depending on composition and temperature. The texture of the ceramic is in general not oriented. Only locally a slight orientation of micas, due to the modeling pressures can be noticed (Pl. I, Fig. 1). Based on the amount of the crystalline components compared with that of the amorphous phases which were formed during the firing, three main fabrics were identified: a) microcrystalline, b) microcrystalline-amorphous and c) amorphousmicrocrystalline to amorphous (table 4). These

\footnotetext{
${ }^{8}$ Fragments of rocks, minerals etc., called clasts in the geological literature (Gary et al. 1977) and inclusions in the geoarchaeological and archaeological literature (Rapp, Hill 1998).
}

support the classification of the tegular material into three main categories, e.g. tegular ceramic material of type I, tegular ceramic material of type II, tegular ceramic material of type III.

The tegular ceramic material of type I (samples 79-2RM, 79-5RM, 79-7RM and 79$14 \mathrm{AI}, 79-15 \mathrm{AI})$ was fired at lower temperatures. The matrix is anisotropic (Pl. I, Figs. 1, 2), having a microcrystalline fabric, with weak sintering processes, which are visible at the contact zones between clay minerals lamellae. The rims of these lamellae become soft, allowing their welding, i.e. the sintering in a coherent whole.

The tegular ceramic material of type II (samples 79-3RM, 79-6RM, 79-8RM, 79-9RM and 79-17AI, 79-21AI), was fired at a higher temperature than the first category. The matrix shows a microcrystalline-amorphous fabric, with the predominance of the crystalline phases i.e. thermally untransformed or slightly transformed clay minerals (sintered). The amorphous phase amount is increasing, due to the distroying of the crystalline structure and due to the incipient melting. In plane-polarized light, under crossed nicols, the matrix is partly isotropic (Pl. I, Figs. 3, 4, 5, 6).

The tegular ceramic material of type III comprises the samples with amorphousmicrocrystalline and amorphous fabric, fired at highest temperatures. In the amorphousmicrocrystalline matrix (samples 79-1RM, 7910RM, 79-12RM and 79-16AI, 79-18AI, 7919AI, 79-23AI) the amorphous phase is predominant, reflecting the melting and the collapsing of the clay minerals structure. The crystalline phase of the matrix contains mica lamellae in a low-birefringent illitic groundmass which is only partly thermally-altered. In planepolarized light, under crossed nicols, the matrix is mostly isotropic (Pl. II, Figs. 7, 8). The almost entirely amorphous matrix (samples 79-11RM and 79-20AI, 79-22AI) reflects the advanced transformation and melting of the clay minerals, at higher firing temperatures. In plan polarized light, under crossed nicols, the matrix is isotropic (Pl. II, Figs. 9, 10), while with one nicol is almost opaque due to the iron oxides and the tiny particles with very different refraction indices (Pl. II, Fig. 11). 
TABLE 4.

THE THERMAL ALTERATION OF THE CLAYISH MATRICES AND CLASTS DURING THE FIRING

\begin{tabular}{|c|c|c|c|c|c|c|c|}
\hline \multirow{2}{*}{$\begin{array}{l}\text { Sample } \\
\text { no. }\end{array}$} & \multicolumn{4}{|c|}{$\begin{array}{c}\text { Matrix } \\
\text { structure }\end{array}$} & \multirow[b]{2}{*}{$\begin{array}{c}\text { Mineralogical changes observed in thin } \\
\text { sections }\end{array}$} & \multirow[b]{2}{*}{$\begin{array}{c}\text { X- Ray } \\
\text { diffractometry } \\
\text { observations }\end{array}$} & \multirow[b]{2}{*}{ 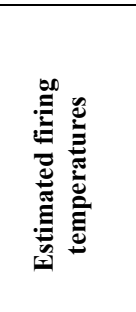 } \\
\hline & 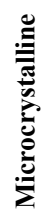 & 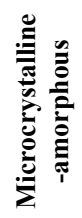 & 竞竞 & $\frac{\mathscr{a}}{\grave{a}}$ & & & \\
\hline 79-1RM & & & + & & $\begin{array}{l}\text { - Intense fissuring of quartz } \\
\text { - Diffusion-migration of Fe from the } \\
\text { matrix towards the quartzitic } \\
\text { clasts } \\
\text { - Absence of calcite } \\
\text { - Glassy rims formed in between clay } \\
\text { minerals lamellae } \\
\text { - Forming of gehlenitic glass }\end{array}$ & $\begin{array}{l}\text { - The most intense } \\
\text { line of calcite } \\
(3.03 \AA) \text { is } \\
\text { missing } \\
\text { - Hematite is present }\end{array}$ & $900-950^{\circ} \mathrm{C}$ \\
\hline 79-2RM & + & & & & $\begin{array}{l}\text { - } \begin{array}{c}\text { Fine-grained limestone, thermally } \\
\text { altered }\end{array} \\
\text { - Large calcite crystals, thermally } \\
\text { unchanged } \\
\text { - Scarce glassy rims formed around the } \\
\text { calcitic clasts } \\
\text { - Thin glassy films intruded into the } \\
\text { fissures in quartz }\end{array}$ & $\begin{array}{l}\text { - Partly destroyed } \\
\text { crystalline structure } \\
\text { of the clay minerals } \\
\text { - The } 3.03 \AA \text { calcite } \\
\text { line is present }\end{array}$ & $800-850^{\circ} \mathrm{C}$ \\
\hline 79-3RM & & + & & & $\begin{array}{l}\text { - Intense fissuring of quartz } \\
\text { - Reaction rims formed between the } \\
\quad \text { clayish matrix and some clasts } \\
\text { - Calcite almost totally thermally } \\
\text { decomposed } \\
\text { - Glassy rims formed in between clay } \\
\text { minerals lamellae } \\
\end{array}$ & $\begin{array}{l}\text { - Small amount of } \\
\text { calcite (weak } 3.03 \AA \\
\text { line) } \\
\text { - Hematite is present } \\
\text { - Gehlenite is } \\
\text { present }\end{array}$ & $850-900^{\circ} \mathrm{C}$ \\
\hline 79-4RM & & & & + & $\begin{array}{l}\text { - Intense fissuring of quartz } \\
\text { - Diffusion-migration of Fe from the } \\
\text { matrix towards the quartzitic } \\
\text { clasts } \\
\text { - Calcite is missing } \\
\text { - Glassy rims formed in between clay } \\
\text { minerals lamellae } \\
\text { - Forming of gehlenitic glass }\end{array}$ & $\begin{array}{l}\text { - Intense destroying of } \\
\text { the clay minerals } \\
\text { structure } \\
\text { - Hematite is present } \\
\text { - Gehlenite is present } \\
\text { - Calcite is missing }\end{array}$ & $900-950^{\circ} \mathrm{C}$ \\
\hline 79-5RM & + & & & & $\begin{array}{c}\text { - } \begin{array}{c}\text { Fissures in quartz } \\
\text { - }\end{array} \begin{array}{c}\text { Presence of fin-grained calcite in the } \\
\text { matrix }\end{array} \\
\text { - } \quad \text { Fine-grained limestone lithoclasts, } \\
\text { lightly decomposed on the } \\
\text { rims } \\
\text { - }\end{array}$ & $\begin{array}{l}\text { - Partly destroyed } \\
\text { crystalline structure } \\
\text { of the clay minerals } \\
\text { - The } 3.03 \AA \text { calcite } \\
\text { line is present }\end{array}$ & $800-850^{\circ} \mathrm{C}$ \\
\hline 79-6RM & & + & & & $\begin{array}{l}\text { - Fissures in quartz } \\
\text { - Contraction holes formed around some } \\
\text { large and well-rounded clasts } \\
\text { - Large calcite crystals, thermally } \\
\quad \text { unchanged } \\
\text { - Fine crystals of calcite, partly thermally } \\
\text { altered }\end{array}$ & $\begin{array}{l}\text { - Partly destroyed } \\
\text { crystalline structure } \\
\text { of the clay minerals } \\
\text { - Calcite is still } \\
\text { present (weak } 3.03 \\
\AA \text { Aline) }\end{array}$ & $800-850^{\circ} \mathrm{C}$ \\
\hline 79-7RM & + & & & & $\begin{array}{l}\text { - Contraction holes formed around some } \\
\quad \text { large and well-rounded clasts } \\
\text { - Fine crystals of calcite, partly thermally } \\
\text { altered } \\
\text { - Partial decomposition of fine-grained } \\
\text { limestone lithoclasts } \\
\text { - Rare glassy rims formed in between } \\
\text { clay minerals lamellae }\end{array}$ & $\begin{array}{l}\text { - Partly destroyed } \\
\text { crystalline structure } \\
\text { of the clay minerals } \\
\text { - Calcite is still } \\
\text { present ( } 3.03 \AA \text { line) }\end{array}$ & $800-850^{\circ} \mathrm{C}$ \\
\hline 79-8RM & & + & & & $\begin{array}{c}\text { - Intense fissuring of quartz } \\
\text { - Contraction holes formed around some } \\
\text { large and well-rounded clasts }\end{array}$ & $\begin{array}{l}\text { - Partly destroyed } \\
\text { crystalline structure } \\
\text { of the clay minerals }\end{array}$ & $850-900^{\circ} \mathrm{C}$ \\
\hline
\end{tabular}




\begin{tabular}{|c|c|c|c|c|c|c|c|}
\hline & & & & & $\begin{array}{l}\text { - Partial decomposition of fine-grained } \\
\text { limestone lithoclasts } \\
\text { - Rare glassy rims formed in between } \\
\text { clay minerals lamellae }\end{array}$ & $\begin{array}{l}\text { - Calcite is still } \\
\text { present (weak } 3.03 \\
\AA \text { line) } \\
\text { - Gehlenite is } \\
\text { present }\end{array}$ & \\
\hline 79-9RM & & + & & & $\begin{array}{l}\text { - Intense fissuring of quartz } \\
\text { - Contraction holes formed around some } \\
\text { large and well-rounded clasts } \\
\text { - Almost totally decomposed calcite } \\
\text { - Glassy rims formed in between clay } \\
\text { minerals lamellae } \\
\end{array}$ & $\begin{array}{l}\text { - Partly destroyed } \\
\text { crystalline structure } \\
\text { of the clay minerals } \\
\text { - Calcite lines are } \\
\text { missing }\end{array}$ & $850-900^{\circ} \mathrm{C}$ \\
\hline 79-10RM & & & + & & $\begin{array}{l}\text { - Intense fissuring of quartz } \\
\text { - Glassy rims formed around some } \\
\text { quartzitic lithoclasts and in } \\
\text { between clay minerals lamellae } \\
\text { - Calcite, very rare } \\
\text { - Glassy rims formed } \\
\text { - Gehlenite crystalls formed }\end{array}$ & $\begin{array}{l}\text { - Partly destroyed } \\
\text { crystalline structure } \\
\text { of the clay minerals } \\
\text { - Calcite is still } \\
\text { present (weak } 3.03 \\
\AA \text { line) } \\
\text { - Gehlenite starts to } \\
\text { form (weak X-Ray } \\
\text { line) }\end{array}$ & $850-900^{\circ} \mathrm{C}$ \\
\hline 79-11RM & & & & + & $\begin{array}{l}\text { - Contraction holes formed around some } \\
\text { large and well-rounded clasts } \\
\text { - Forming of large quantities of glass } \\
\text { - Diffusion-migration of Fe from the } \\
\text { matrix towards the quartzitic } \\
\text { clasts }\end{array}$ & $\begin{array}{l}\text { - Complete destroying } \\
\text { of the clay minerals } \\
\text { structure } \\
-\quad \text { Gehlenite is } \\
\text { present } \\
- \text { Wollastonite is } \\
\text { present }\end{array}$ & $900-950^{\circ} \mathrm{C}$ \\
\hline 79-12RM & & & + & & $\begin{array}{l}\text { - Intense fissuring of quartz } \\
\text { - Partial decomposition of fine-grained } \\
\text { limestone lithoclasts } \\
\text { - Glassy rims formed in between clay } \\
\text { minerals lamellae }\end{array}$ & $\begin{array}{l}\text { - Partly destroyed } \\
\text { crystalline structure } \\
\text { of the clay minerals } \\
-\quad \text { Calcite is still } \\
\text { present }(3.03 \AA \text { line })\end{array}$ & $850-900^{\circ} \mathrm{C}$ \\
\hline 79-14AI & + & & & & $\begin{array}{l}\text { - Rare fissures in quartz } \\
\text { - Partial decomposition of fine-grained } \\
\text { limestone lithoclasts }\end{array}$ & $\begin{array}{l}\text { - Partly destroyed } \\
\text { crystalline structure of } \\
\text { the clay minerals } \\
\text { - Calcite is still present } \\
\text { ( } 3.03 \AA \text { line) }\end{array}$ & $800-850^{\circ} \mathrm{C}$ \\
\hline 79-15AI & + & & & & $\begin{array}{l}\text { - Rare fissures in quartz } \\
\text { - Partial decomposition of fine-grained } \\
\text { limestone lithoclasts } \\
\text { - Gehlenite rims formed around some } \\
\text { fine-grained limestone } \\
\text { lithoclasts, at the contact with } \\
\text { the matrix }\end{array}$ & $\begin{array}{l}\text { - Partly destroyed } \\
\text { crystalline structure of } \\
\text { the clay minerals } \\
\text { - Calcite is still present } \\
(3.03 \AA \text { line })\end{array}$ & $800-850^{\circ} \mathrm{C}$ \\
\hline 79-16AI & & & + & & $\begin{array}{l}\text { - Intense fissuring of quartz } \\
\text { - Gehlenite rims formed around some } \\
\text { fine-grained limestone } \\
\text { lithoclasts, at the contact with } \\
\text { the matrix } \\
\text { - Microcrystalline calcite from the } \\
\text { matrix is decomposed }\end{array}$ & $\begin{array}{l}\text { - Partly destroyed } \\
\text { crystalline structure of } \\
\text { the clay minerals } \\
\text { - Calcite is still present } \\
\text { ( } 3.03 \AA \text { line) } \\
\text { - Gehlenite is present }\end{array}$ & $850-900^{\circ} \mathrm{C}$ \\
\hline 79-17AI & & + & & & $\begin{array}{l}\text { - Rare fissures in quartz } \\
\text { - Partial decomposition of fine-grained } \\
\text { limestone lithoclasts }\end{array}$ & $\begin{array}{l}\text { - Partly destroyed } \\
\text { crystalline structure of } \\
\text { the clay minerals } \\
\text { - Calcite is still present } \\
\text { (weak } 3.03 \AA \text { line) } \\
\text { - Hematite is present }\end{array}$ & $800-850^{\circ} \mathrm{C}$ \\
\hline 79-18AI & & & + & & $\begin{array}{l}\text { - Intense fissuring of quartz } \\
\text { - Fine-grained limestone clasts, } \\
\text { strongly thermally } \\
\text { transformed: reaction- } \\
\text { decomposition rims are } \\
\text { present } \\
\text { - Microcrystalline calcite from the } \\
\text { matrix is decomposed } \\
\text { - Fine glassy rims formed in between } \\
\text { clay minerals lamellae }\end{array}$ & $\begin{array}{l}\text { - Partly destroyed } \\
\text { crystalline structure of } \\
\text { the clay minerals } \\
\text { - Calcite is still present } \\
\text { (weak } 3.03 \AA \text { line) } \\
\text { - Hematite is present } \\
\text { - Gehlenite is present }\end{array}$ & $850-900^{\circ} \mathrm{C}$ \\
\hline 79-19AI & & & + & & $\begin{array}{l}\text { - Intense fissuring of quartz } \\
\text { - Diffusion-migration of Fe from the } \\
\text { matrix towards the quartzitic } \\
\text { clasts }\end{array}$ & $\begin{array}{l}\text { - Complete destroying } \\
\text { of the clay minerals } \\
\text { structure } \\
\text { - Gehlenite is present }\end{array}$ & $900-950^{\circ} \mathrm{C}$ \\
\hline
\end{tabular}




\begin{tabular}{|c|c|c|c|c|c|c|}
\hline & & & & $\begin{array}{l}\text { - Calcite is decomposed } \\
\text { - Forming of gehlenitic glass }\end{array}$ & $\begin{array}{l}\text { - Wollastonite is } \\
\text { present }\end{array}$ & \\
\hline $79-20 \mathrm{AI}$ & & & + & $\begin{array}{c}\text { - Intense fissuring of quartz } \\
\text { - Fine-grained limestone strongly } \\
\text { thermally altered, with } \\
\text { reaction rims } \\
\text { - Diffusion-migration of Fe from the } \\
\text { matrix towards the quartzitic } \\
\text { clasts } \\
\text { - Forming of gehlenitic glass }\end{array}$ & $\begin{array}{l}\text { - Complete destroying } \\
\text { of the clay minerals } \\
\text { structure } \\
\text { - Calcite is missing } \\
\text { - Gehlenite is present }\end{array}$ & $900-950^{\circ} \mathrm{C}$ \\
\hline $79-21 \mathrm{AI}$ & + & & & $\begin{array}{l}\text { - Rare fissures in quartz } \\
\text { - Fine-grained limestone clasts, } \\
\text { thermally altered } \\
\text { - Totally decomposed fine-grained } \\
\text { calcite from the matrix } \\
\text { - Microfossil remnants from the matrix } \\
\text { are slightly thermally altered }\end{array}$ & $\begin{array}{l}\text { - Partly destroyed } \\
\text { crystalline structure of } \\
\text { the clay minerals } \\
\text { - Calcite is still present } \\
\text { (weak } 3.03 \AA \text { line) }\end{array}$ & $850-900^{\circ} \mathrm{C}$ \\
\hline $79-22 \mathrm{AI}$ & & & + & $\begin{array}{l}\text { - Intense fissuring of quartz } \\
\text { - Diffusion-migration of Fe from the } \\
\text { matrix towards the quartzitic } \\
\text { clasts } \\
\text { - Microcrystalline calcite from the } \\
\text { matrix is decomposed } \\
\text { - Fine-grained limestone clasts are } \\
\text { almost isotropic }\end{array}$ & $\begin{array}{l}\text { - Complete destroying } \\
\text { of the clay minerals } \\
\text { structure - calcite is } \\
\text { missing } \\
\text { - Gehlenite is present } \\
\text { - Wollastonite is } \\
\text { present }\end{array}$ & $900-950^{\circ} \mathrm{C}$ \\
\hline $79-23 \mathrm{AI}$ & & + & & $\begin{array}{l}\text { - Intense fissuring of quartz } \\
\text { - Fine-grained limestone clasts are } \\
\text { almost isotropic }\end{array}$ & $\begin{array}{l}\text { - Complete destroying } \\
\text { of the clay minerals } \\
\text { structure } \\
\text { - Calcite is missing } \\
\text { - Gehlenite is present } \\
\text { - Wollastonite is } \\
\text { present }\end{array}$ & $900-950^{\circ} \mathrm{C}$ \\
\hline
\end{tabular}

It is quite difficult to establish the precise mineral composition of the matrix based only on microscopy, because of the small sizes of the particles and the thermal, irreversible changes in different degrees of intensity. Kaolinite should have been present in the raw clays, to mantain the plasticity. As kaolinite starts to decompose at temperatures above $550-600^{\circ} \mathrm{C}$ (Cultrone et al. 2001) changing into an amorphous mass and disappears completely as individual mineral species shortly above $650^{\circ} \mathrm{C}$ (Bruhns, Fischer 2001), it couldn't be identified in our samples, which were fired at temperatures above $800^{\circ} \mathrm{C}$. For the samples fired below $900^{\circ} \mathrm{C}$ a mainly illitic composition could be recognized by high anisotropy under crossed nicols (Pl. I, Figs. 1-6). The process of the progressive formation of the amorphous phase is shown in Pl. II, Figs. 7-10. The higher the firing temperature, the more increased the amount of glass and subsequently the amorphous character of the matrix intensifies. The ubiquitous hematite, resulted from the thermal transformation of iron oxihydroxides contained in the raw clays gives the reddish colour and sometimes opacity to the matrix.

\section{Clasts (Inclusions)}

In the clayish matrix of the tegular artefacts both from Roşia Montană and Alba Iulia, crystals (crystalloclasts), rocks (lithoclasts), waste ceramics (ceramoclasts, potsherds) and sometimes microfossils (bioclasts) fragments are present. All these clasts represent nonplastic material, called temper as a rule.

Metamorphic, magmatic and sedimentary lithoclasts were identified. The distribution of the lithoclasts (table 5) reveals no major differences between the Roşia Montană and Alba Iulia samples. The metamorphic lithoclasts are ubiquitous in all samples being representeded mainly by quartzites (Pl. I, Figs. 1-6; Pl. II, Figs. 7-10), gneisses, micaschists (Pl. II, Fig. 8). Magmatic lithoclasts are present in all samples, both at Roşia Montană and Alba Iulia, with the prevalence of the Jurassic magmatics known as „ophiolites: basalts (Pl. I, Fig. 3), basaltic andesites (Pl. II, Fig. 11), rarely dolerites. They are followed, as frequency, by Neogene volcanics fragments: andesites (Pl. I, Fig. 4), dacites (Pl. II, Fig. 10), rhyolites. In the most of 
Table 5.

Petrographical composition of the lithoclasts

\begin{tabular}{|c|c|c|c|c|c|c|c|c|c|c|c|c|c|}
\hline \multirow[t]{2}{*}{ Sample no. } & \multicolumn{4}{|c|}{ Metamorphic rocks } & \multicolumn{4}{|c|}{ Magmatic rocks } & \multicolumn{5}{|c|}{ Sedimentary rocks } \\
\hline & 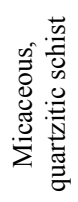 & $\begin{array}{l}\frac{n}{0} \\
\tilde{D}\end{array}$ & 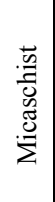 & 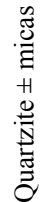 & 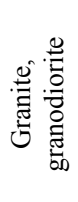 & 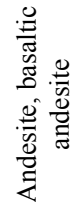 & 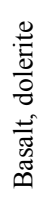 & 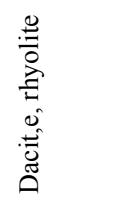 & 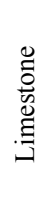 & 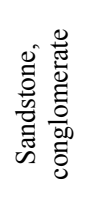 & 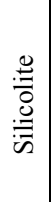 & 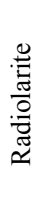 & 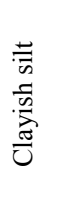 \\
\hline 79-1RM & & + & & + & & + & + & & & & & & \\
\hline 79-2RM & + & & & + & + & + & & & + & + & & & \\
\hline 79-3RM & + & + & & + & + & + & & + & & & & & + \\
\hline 79-4RM & + & + & & + & + & + & + & & & & + & & + \\
\hline 79-5RM & & & + & + & + & + & + & & + & + & & & \\
\hline 79-6RM & + & & & + & & & + & + & + & & + & & \\
\hline 79-7RM & & & & + & + & & + & & + & + & & & \\
\hline 79-8RM & & + & & + & & + & + & + & & & & & \\
\hline 79-9RM & + & & & + & & + & & & & & & + & \\
\hline 79-10RM & & & & + & & + & + & & & + & & & \\
\hline 79-11RM & & & & + & & & + & + & & & + & & \\
\hline 79-12RM & + & & & + & + & + & + & & + & & & & \\
\hline & & & & & & & & & & & & & \\
\hline 79-14AI & & & & + & + & + & + & & + & & & & + \\
\hline 79-15AI & & & & + & & & + & + & + & + & & + & + \\
\hline 79-16AI & & & & + & + & + & + & + & + & & + & & + \\
\hline 79-17AI & & + & & + & + & & + & + & & & + & & \\
\hline 79-18AI & + & + & & + & + & & + & + & & + & & & \\
\hline 79-19AI & & & & + & + & & & & & & + & & \\
\hline 79-20AI & & + & & + & + & + & & & & & & + & \\
\hline 79-21AI & & & + & + & + & + & + & & + & + & & & \\
\hline $79-22 \mathrm{AI}$ & & & & + & & & & + & & & & & \\
\hline 79-23AI & & + & & + & + & & + & & & & & & \\
\hline
\end{tabular}

the samples granite-granodiorite fragments ( $\mathrm{Pl}$. I, Figs. 3, 5, 6) could be seen as well. Sedimentary lithoclasts as limestones (P1. I, Fig. 6; Pl. II, Fig. 8), sandstones-conglomerates, silicolites (P1. I, Fig. 5), clayish silts are equally distributed in the two localities. The presence of radiolarites $^{9}$ (which are, geologically, associated to „ophiolites") both in the Roşia Montană and the Alba Iulia samples has to be mentioned as well.

The crystalloclasts are represented mainly by quartz (P1. I, Figs. 1-6; P1. II, Figs. 712), plagioclase and potassic feldspar (Pl. I, Figs. 2, 3, 6; P1. II, Figs. 8 - 10) fragments. Mica lamellae (muscovite, rarely biotite) (P1. I, Figs. 1-6; P1. II, Figs. 7-9) are ubiquitous. Heavy minerals are quite rare and occur as pyroxene (Pl. I, Fig. 6; Pl. II, Fig. 10), hornblende, garnet, apatite, epidote and opaque minerals (See also Ionescu, Ghergari 2005) fragments.

\footnotetext{
${ }^{9}$ See the glossary.
}

The bioclasts are also scarce, as e.g. Radiolaria skeleton remnants (samples 7911RM, 79-18AI, 79-20AI) originating from radiolarite rocks. Remnants of calcareous foraminifera are very rare (sample 79-21AI). The presence of ceramoclasts is only accidental (samples 79-6RM and 79-8RM).

\section{3. $X$-Ray diffraction}

For the precise identification of the mineral species of the ceramic tegular material and for the outlining the firing alteration supported by some components (Ghergari, Ionescu 2000), X-Ray powder diffraction analyses were used.

Compared with the standard data (Bayliss et al. 1986), the diffraction patterns of the Roşia Montană and Alba Iulia samples (Figs. 3, 4) show the presence of quartz and feldspar (representing lithoclasts and crystalloclasts), clay minerals, micas and calcite (representing the matrix). It was not possible to specify the primary clay minerals species 
because their structure has been partly or even totally distroyed by firing. Only two diffraction lines are marked ( $\sim 4.5$ and $\sim 2.6 \AA$ ), common to illite, kaolinite and some smectites, and which reflect the partial preservation of some undisturbed crystalline structures.

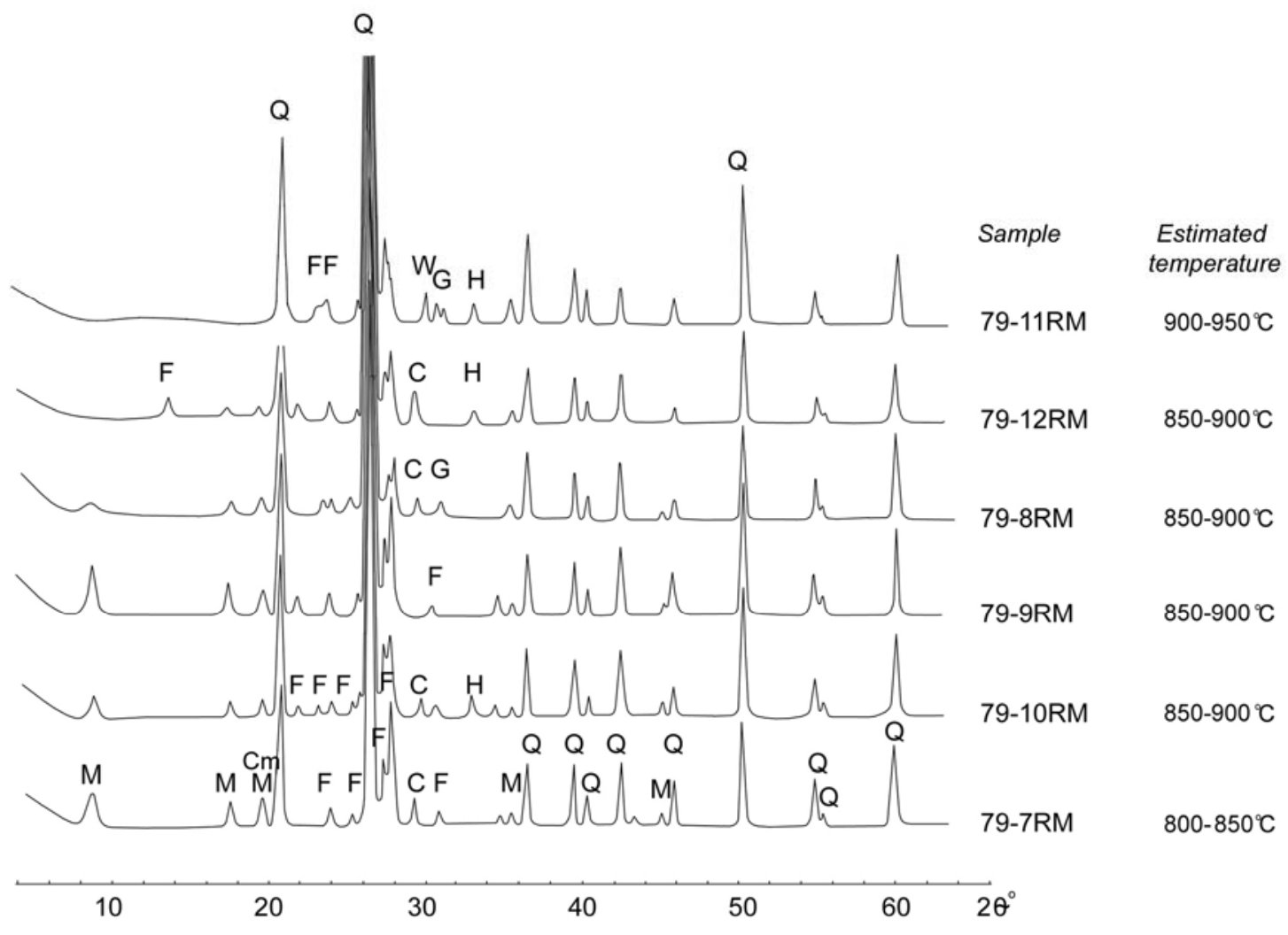

Fig. 3. X-Ray diffractograms for some Roșia Montană samples. $Q$ for quartz, $F$ for feldspar, $C$ for calcite, $M$ for micas, $C m$ for clay minerals, $H$ for hematite, $G$ for gehlenite, $W$ for wollastonite.

Calcite starts to decompose at about $800^{\circ} \mathrm{C}$ being totally distroyed between 900 and $950^{\circ} \mathrm{C}$. The presence of the $3.03 \AA$ calcite line shows a temperature lower than $900^{\circ} \mathrm{C}$. A well shaped and evident calcite line means not only a lower firing temperature but mainly the presence of large limestone-lithoclasts. The weak, less intense calcite lines may indicate both a low amount of untransformed finegrained calcite in the matrix and its thermal decomposition.

New thermally-formed minerals, as hematite, gehlenite and wollastonite were identified in both Roşia Montană and Alba Iulia samples. In the sample 79-19AI there is also a weak line (Fig. 4) which could represent mullite - a mineral formed mainly from kaolinite, at high temperatures, above $950^{\circ} \mathrm{C}$.

\section{THERMAL TRANSFORMA-TIONS} OF MINERAL PHASES

The microscopical observations in thin sections revealed a number of thermal changes affecting some mineral components of the ceramic tegular materials. Based on references (Duminuco et al. 1998; Gualtieri, Venturelli 1999; Riccardi et al. 1999; Cairo et al. 2001; Cultrone et al. 2001; Antonelli et al. 2002; Kacim, Hajjaji 2003; Maritan 2004; Cultrone et al. 2005), on the X-Ray diffraction patterns as well as on our previous experimental results ${ }^{10}$, we inferred the firing temperatures (table 4) for the ceramics.

\footnotetext{
${ }^{10}$ Thermal experiments on clayish raw materials from Transylvania (Romania) supported by the 1762 CNCSIS Grant of the Romanian Ministry of Education and Research (2003-2005).
} 


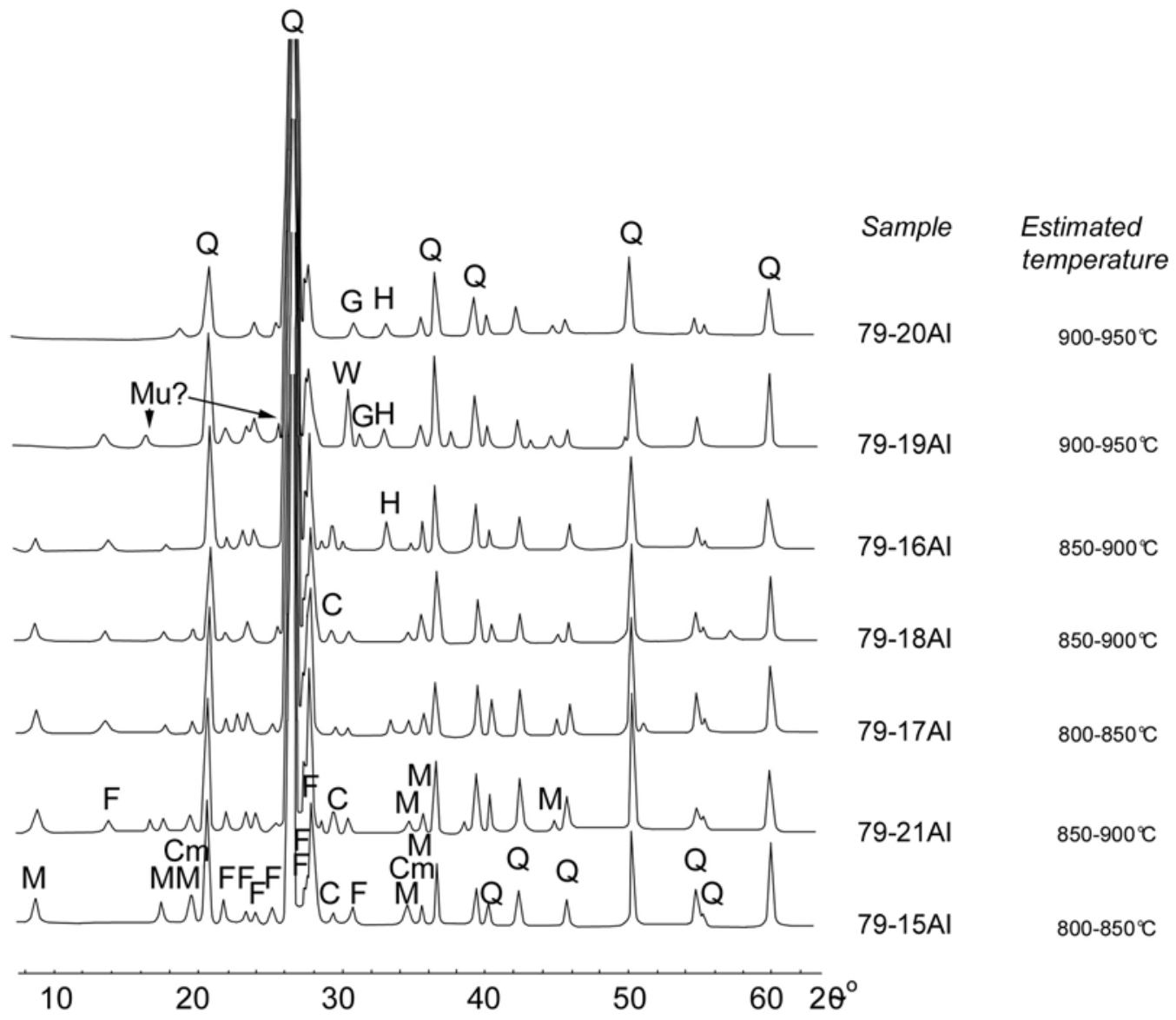

Fig. 4. -Ray diffractograms for some Alba Iulia samples. Q for quartz, F for feldspar, C for calcite, M for micas, Cm for clay minerals, $H$ for hematite, $G$ for gehlenite, $W$ for wollastonite, Mu for mullite.

It is known that the presence of hematite indicates a firing temperature of minimum $800^{\circ} \mathrm{C}$ and gehlenite and wollastonite at least $800-850^{\circ} \mathrm{C}$. Above $850-900^{\circ} \mathrm{C}$, the melting of the matrix is a common process, the glass quantity depending not only on the composition and temperature but probably also on the the firing length of time. The presence of finegrained calcite in the ceramics means temperatures of maximum $850^{\circ} \mathrm{C}$. Some X-Ray diffraction lines of clay minerals (illite, smectite) diminished starting with $750-800^{\circ} \mathrm{C}$ and disappear totally above a $850-900^{\circ} \mathrm{C}$ temperature of firing.

Nevertheless, in the tegular ceramic material of type I (samples 79-2RM, 79-5RM, 79-6RM, 79-7RM and 79-14AI, 79-15AI, 79$17 \mathrm{AI}$ ), firing temperatures of about $800-850^{\circ} \mathrm{C}$ are indicated by the followings:
- Large grains of calcite, thermally unaffected (Roşia Montană);

- Scarce formation of glassy films, in between the grains of matrix (Roşia Montană, Alba Iulia);

- The fissuring of quartz (Roşia Montană, Alba Iulia);

- Fine-grained calcite, partly thermally altered (Roşia Montană, Alba Iulia);

- Contraction holes formed around some large and well-rounded clasts (Roşia Montană, Alba Iulia);

- The main X-Ray diffraction lines of calcite are present (Roşia Montană, Alba Iulia);

- X-Ray patterns show the partial destroying of the clay minerals structure (Roşia Montană, Alba Iulia).

Higher temperatures, of about $850-900^{\circ} \mathrm{C}$ for the type II tegular ceramic materials 
(samples 79-3RM, 79-8RM, 79-9RM, 7910RM, 79-12RM and 79-16AI, 79-18AI, 79$21 \mathrm{AI})$ were inferred from:

- The network-like fissuring of quartz (Roşia Montană, Alba Iulia);

- Glassy rims formed around quartz grains or in between clay minerals lamellae (Roşia Montană, Alba Iulia);

- Fine-grained calcite from the matrix is entirely decomposed (Alba Iulia);

- Contraction holes formed around some large and well-rounded clasts (Roşia Montană, Alba Iulia);

- Partial decomposition of fine-grained limestone lithoclasts (Roşia Montană);

- Reaction rims at the contact between matrix and quartzitic clasts (Roşia Montană, Alba Iulia);

- Gehlenite forming at the contact between the clayish matrix and $\mathrm{CaO}$ resulted from the fine-grained calcite decomposition (Roşia Montană, Alba Iulia);

- The partial destroying of the clay minerals structure reflected in the X-Ray pattern (Roşia Montană, Alba Iulia);

- Main X-Ray calcite line (3.03 $\AA$ ) is weak (Roşia Montană, Alba Iulia);

- The presence of X-Ray lines of hematite and gehlenite (Roşia Montană, Alba Iulia).

The highest temperatures belong to the type III tegular ceramic material (samples 791RM; 79-4RM, 79-11RM and 79-19AI, 7920AI, 79-22AI, 79-23AI), i.e. the $900-950^{\circ} \mathrm{C}$ interval. They are marked by the followings:

- The pronounced increasing of melt, respectively glass amount (Pl. II, Fig. 11) (Roșia Montană);

- Diffusion-migration of $\mathrm{Fe}$ from the matrix towards the quartzitic clasts (Pl. II, Fig. 12) (Roşia Montană, Alba Iulia);

- The network-like intense fissuring of quartz (Roşia Montană, Alba Iulia);

- Gehlenite and/or wollastonite forming (Roșia Montană, Alba Iulia);

- Contraction holes formed around some large and well-rounded clasts (Roşia Montană, Alba Iulia);

- Total decomposition of the fine-grained calcite from the matrix as well as the limestone clasts (Roşia Montană, Alba Iulia);
- Fine-grained limestone clasts are almost isotropic (Alba Iulia);

- The forming of glass with gehlenitic composition (Roşia Montană, Alba Iulia);

- The complete destroying of the clay minerals structure reflected in the X-Ray pattern (Roşia Montană, Alba Iulia);

- The presence of X-Ray lines of hematite, gehlenite, wollastonite (Roşia Montană, Alba Iulia).

In general, the thermal processes which affected the ceramic mixture during the firing are similar for the Roșia Montană and Alba Iulia samples (table 4). The distribution of the samples vs. firing temperature is shown in Fig. 5. The Alba Iulia samples seem to be better fired (at $850-950^{\circ} \mathrm{C}$ ), while the Roşia Montană is mainly fired at slightly lower temperatures $\left(800-900^{\circ} \mathrm{C}\right)$.

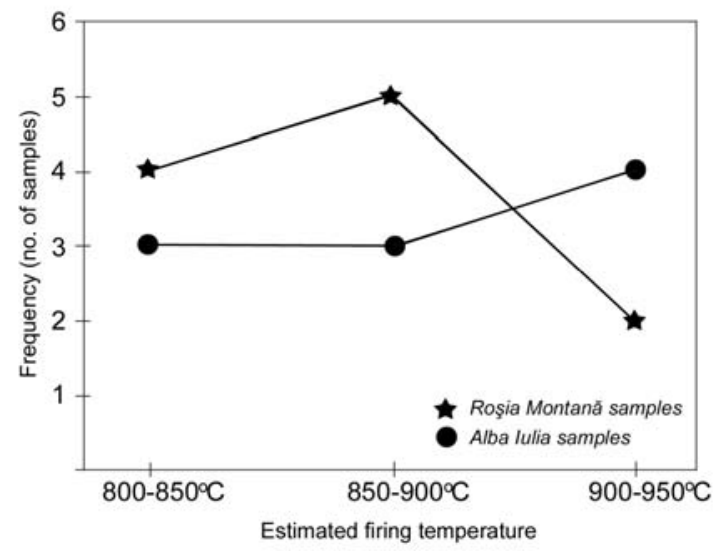

Fig. 5. Frequency vs. estimated firing temperatures diagram for the tegular ceramic materials from Roşia Montană and Alba Iulia.

\section{RAW MATERIALS AND FIRING CONDITIONS: DISCUSSIONS}

For producing the tegular ceramic materials, raw clays and temper materials were used.

\subsection{Sources of raw clayish materials}

Based on microscopic studies (on matrix) as well as on X-Ray diffractometry (on whole ceramic body), we presume that the raw materials used for both Roşia Montană and Alba Iulia tegular ceramic artefacts were similar, i.e. polymictic clays (illitic-kaolinitic or illitickaolinitic-smectitic), more or less calcareous, 
with mica and iron oxihydroxides content. However, we have to take into account the fact that the comparison of the mineralogical characteristics of the ceramics with those of the presumed sources cannot offer completely precise informations because a) in general, for the ceramic paste a mixture of several clays might have been used and $b$ ) the adding of the temper materials might also have altered the characteristics of the clayish mixture.
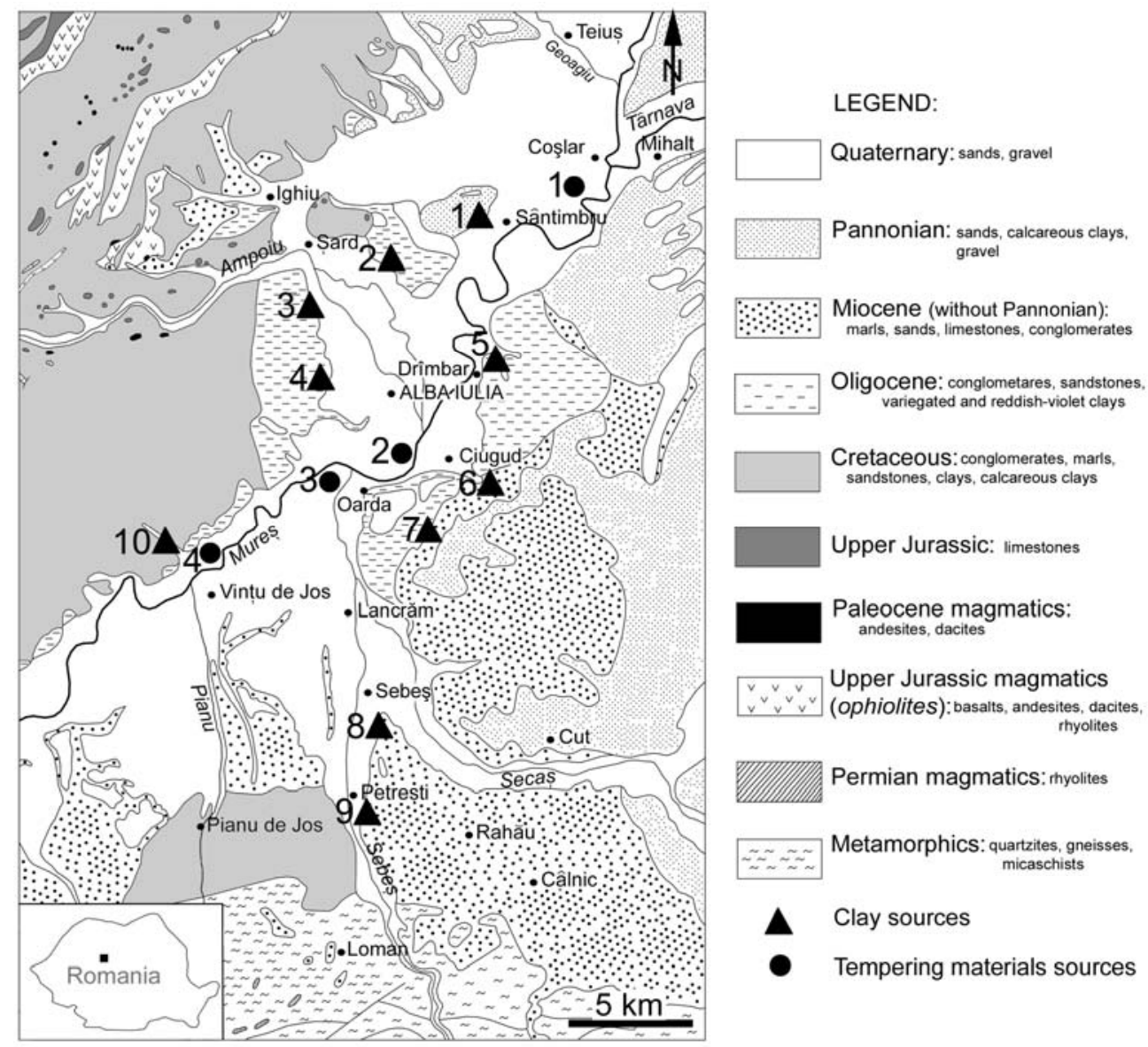

Fig. 6. Geological map of the Alba Iulia area (acc. to the Geological map of Romania, 1:200,000, Turda File, $1967 \&$ Orăştie File, 1968) with the location of actual clays and sands sources. For clays: 1- Sântimbru, 2 - Şard, 3 \& 4 Alba Iulia, 5 - Drîmbar, 6 - Ciugud, 7 - Oarda, 8 - Sebeş, 9 - Petreşti, 10 - Vințu de Jos. For temper (sands): 1 Coşlar-Sântimbru, 2 - Şard, 3 - Alba Iulia, 4 -Vințu de Jos.

The various and extended clay deposits occurring in the surroundings of Alba Iulia could represent ancient raw materials. They are still used for obtaining tegular artefacts as, bricks and tiles (Fig. 6) (Pârvu et al. 1977; Mihăilescu, Grigore 1981):

- Near Sântimbru Pannonian polymictic (illitic-kaolinitic-smectitic) clays are still mined (location $1 \mathbf{\Lambda}$ );

- Variegated and reddish-violet, illitickaolinitic, ferruginous clays, slightly calcareous, of Oligocene age, occur in the Sard area (location $2 \mathbf{\Delta}$ ) and west of Alba Iulia (locations 3 and $4 \mathbf{\Lambda}$ );

- East of Alba Iulia, near the village of Drîmbar, on the left side of the Mureş (location $5 \Delta$ ), occur the same variegated and reddishviolet, illitic-kaolinitic, ferruginous, slightly calcareous clays, of Oligocene age as in the location 2;

- At Ciugud (location $6 \mathbf{\Delta}$ ) a 3-8 m thick layer of yellow-reddish smectitic, low illitic 
clay is mined. The clay formed by alteration of Miocene volcanic tuffs and contains remnants of these tuffs. It is used for the tegular ceramic as well as for the pottery production;

- A yellowish, smectitic, low-illitic clay, similar with the Ciugud clay, is mined towards south, in the Oarda neighbourhood (location $7 \mathbf{\Lambda})$;

- Near Sebeş (location 8 $\mathbf{\Delta}$ ), clays similar to that from Ciugud and Oarda is used for the bricks production;

- Near Petreşti (southwest of Sebeş) (location 9 $\mathbf{\Delta}$ ), clays similar to that from Ciugud and Oarda is used for bricks and tiles production;

- A greyish-violetish illitic-kaolinitic, calcareous clay, of Cretaceous age, is mined at Vinţu de Jos (location 10 $\mathbf{\Delta}$ ).

Among the above-listed sources, those from Ciugud (loc. 6), Oarda (loc. 7), Sebeş (loc. 8) and Petreşti (loc. 9) are associated with clayish rocks formed by volcanic tuffs alteration, but in our samples no fragment of such tuffs has been found. In order to mine the Drimbar clay (loc. 5), it is difficult to envisage that the Romans transported the raw material across the Mureş river, while similar clays could be more easily mined near Şard (loc. 2) or west of Alba Iulia (loc. 3 and 4). The clays from Vințu (loc. 10) would have been a suitable raw material but they are located relatively far from Alba Iulia and additionally, the thickness of the deposit is small.

Taking into consideration the mineralogical composition of the ceramics matrix (illite, kaolinite \pm smectite \pm calcite + micas + iron oxides), we presume that for the Alburnus Major (Roşia Montană) and Apulum (Alba Iulia) tegular material, clays with similar composition which occur west of Sântimbru (loc. 1), east of Şard (loc. 2) and west of Alba Iulia (loc. 3 and 4) were used. These clayish deposits offer even nowadays good raw materials for bricks and tiles production.

\subsection{Temper sources}

Comparing the distribution of various petrographical types of lithoclast in the tegular material from Roşia Montană and Alba Iulia (table 4) it is obvious that there are no major differences between the two sites, indicating that similar quartz sands were used, i.e. common temper sources.

The characteristics of temper sources could be inferred from the petrography of some lithoclasts and mineralogy of some crystalloclasts. Metamorphic fragments as quartzites, gneisses, micaschists are present in all samples. Such rocks are common to both, the Apuseni Mts. and Southern Carpathians (Geological Map of Romania, Turda Sheet 1967 and Orăştie Sheet 1968), and the Eastern Carpathians (Geological Map of Romania, Toplița Sheet 1968). They occur as fragments in the alluvial sediments of the Arieş, Geoagiu, Ampoi, Sebeş or Pianu rivers, as well as in the Mureş river alluvias, including upstream the junction with the Arieş river. This is the reason why in our case, the metamorphic lithoclasts do not have a high diagnostic value in temper source identification.

The magmatic lithoclasts occur also in all samples. Both in the Roşia Montană and the Alba Iulia tegular ceramic material, fragments of the Jurassic rocks known as „ophiolites” (basalts, basaltic andesites, as well as dacites, andesites, rhyolites) are prevalent. They are similar to the rocks outcropping on a SW-NE striking band, west and north-west of Alba Iulia (Fig. 6), but they no not occur in the Roşia Montană area (Geological Map of Romania, Turda Sheet 1967). Fragments of such ophiolitic rocks are common in the Mureş river alluvial sediments, downstream of the junction with the Arieş river, as well as in the alluvias of right-sided affluents of the Mureş, as Arieş, Aiud, Geoagiu, Ampoi rivers. The presence in the ceramics, of radiolarite lithoclasts and Radiolaria bioclasts identical with those accompanying the ophiolites, deserves mentioning too.

On the second place regarding the frequency, granite-granodiorite lithoclasts are found in the samples. They are similar to granodiorites from Iara and granites of Muntele Mare massif and were transported by the Arieş river into Mureş (Geological Map of Romania, Turda Sheet 1967).

The third place based on frequency belongs to the fragments of Neogene volcanics, similar to andesites occurring in the hydrographic basin of the Ampoi river, to 
andesites and dacites from the Roşia Montană (Geological Map of Romania, Turda Sheet 1967) area or to andesites from the Eastern Carpathians ${ }^{11}$. West of Alba Iulia there are also small bodies of Paleogene magmatics as andesites and dacites (Fig. 6) but we consider that the similar rocks present in the tegular material belong not to these magmatics but rather to ophiolites and/or to Neogene volcanics.

From the sedimentary rocks, the most important from the temper source identification are limestones fragments, similar to the Jurassic rocks accompanying the ophiolites, which do not occur in the Roşia Montană area (Geological Map of Romania, Turda Sheet 1967). Fragments of such rocks occur on the lower Arieş river, as well as in the alluvias of the Aiud, Geoagiu, Ampoi rivers and consequently in the Mureş alluvial sediments downstream the junction with the Arieş river.

The crystalloclasts originate from the disintegration of various rocks (metamorphics, magmatics, sediments) and do not give a precise indication of the source.

Regarding the provenance of the quartz sands used as temper material, they could most probably come from one of the well-known occurrences in the area (Fig. 5) (Mihăilescu, Grigore 1981):

- Quartz sands used as temper for ceramic industry are actually mined from the Mureş river bed (location 1•) in the CoşlarSântimbru area;

- The alluvial sediments of the Mureşului, east of Alba Iulia (location 2•), contain quartz sands, used for production of tiles and bricks;

- In the Oarda area, on the left side of the Mureş river, quartz sands are mined (location 3•);

- Near Vințu de Jos, the alluvial sediments of the Mureş river give a greyishyellowish quartzititc sand used as temper in the ceramic industry (location $4 \bullet$ ).

The mineralogical and petrographical composition of the crystalloclasts and

\footnotetext{
${ }^{11}$ These mountains are also crosscut by the Mureş river; see Geological Map of Romania, Bistrița Sheet 1967 and Toplița Sheet 1968.
}

lithoclasts respectively, both in the Roşia Montană and the Alba Iulia samples, is similar. If we take into account the frequency of some lithoclasts, as granites-granodiorites (similar to those found in the Arieş hydrographic basin, north of Alba Iulia), basalts, basaltic andesites, andesites, dacites, rhyolites, radiolarites (surely originated from the mesozoic ophiolitic area occurring west of Alba Iulia) and limestones (oucropping west of Alba Iulia, together with ophiolites) both in the tegular ceramic material and in the alluvial quartz sands of the Mureş river downstream the junction with the Ampoi river, we presume that the temper was most likely mined on the right bank of the Mureş river, south-east of Alba Iulia. This area gives quartz sands used even today for tegular artefacts (bricks, tiles) production (Fig. 6).

\subsection{Firing conditions}

The microscopical and X-Ray diffraction data support some considerations regarding the technology used for the tegular artefacts production. The clayish raw material, mixed with variable amounts of water and quartz sands (temper) was quite well-kneaded, the fact which is reflected in the homogeneity of the ceramic body even at microscopical level. When a suitable plasticity was achieved, the bricks and tiles were shaped by pressing in some moulds and naturally dried. The firing was performed most probably in kilns having a separate combustion room. The burning oxidizing atmosphere can be deduced from the massive presence of the red, hematitic pigment.

The estimated temperatures range from 800 up to $950^{\circ} \mathrm{C}$. The width of the interval is probably due to the unhomogeneous distribution of heat inside the kiln, as well as to the impossibility of temperature control and/or to the variable length of time allowed for the firing. It is possible that artefacts presenting different degrees of thermal alteration resulted together, even if they were fired at one and the same time. Three main firing intervals were separated: $800-850^{\circ} \mathrm{C}, 850-900^{\circ} \mathrm{C}$ and $900-$ $950^{\circ} \mathrm{C}$. 


\section{CONCLUSIONS}

Among all legions located in the Roman Dacia, the Legion XIII Gemina was the most closely related to the history of the province, as it participated at the construction of many military camps and roads. The LEG XIII GEM (GE, G) are the earliest stamps, dating mainly from the first part of the second century A.D. and were found at Apulum as well as in the province territory. Besides the tegular material exhumed at Apulum and which represents a point of reference for our analogies, the samples containing similar stamps, found on the province territory are also very important (Țentea 2003, 256-257.). From typological point of view, all stamps discovered so far at Alburnus Maior (in the E1 and E2 buildings) can be chronologically-framed in the first half of the second century A.D.

The study of the twenty two samples of tegular ceramic artefacts (bricks and tiles) belonging to the Legion XIII Gemina and exhumed at Roşia Montană (Alburnus Maior) and Alba Iulia (Apulum) showed that:

- The material is homogeneous, in colour and composition. It consists of a clayish matrix with crystalline and/or amorphous fabric, in which temper particles as lithoclasts and crystalloclasts occur as well.

- Regarding the grain size, the ceramics is mainly lutitic-siltic-arenitic, with a contribution of arenaceous-sized grains exceeding $15 \%$ and reflecting the coarse category for all samples.

- Microscopical data of the matrix and the X-Ray diffractometry of the whole ceramic sample indicate that polymictic ferruginous clays, composed mainly from illite, kaolinite \pm smectite \pm calcite were used as raw materials both for the Roşia Montană and the Alba Iulia artefacts.

- The lithoclasts and crystalloclasts composition indicate that quartz sands were used as temper. Quartzites, granitesgranodiorites, basalts, andesites and basaltic andesites, gneisses and limestones are ubiquitous lithoclasts.

- The firing temperatures were inferred from the thermal changes of the primary minerals such as quartz fissuring, calcite decomposition, forming of contraction holes around some clasts, the change of the anisotropy of some minerals, and the meltglass, gehlenite, hematite and wollastonite forming. The X-Ray diffraction patterns such as the disappearance of some clay minerals lines, the presence of hematite, gehlenite and wollastonite lines, the alteration of calcite lines etc. supported the temperature estimations. Based on the estimated firing temperatures, the tegular ceramic samples were classified into three categories: a) tegular ceramic material of type I, fired at lowest temperatures, between 800 and $850^{\circ} \mathrm{C}$;

b) tegular ceramic material of type II, fired around $850-900^{\circ} \mathrm{C}$ and c) tegular ceramic material of type III, fired up to $900-950^{\circ} \mathrm{C}$. The Alba Iulia samples were fired at slightly higher temperatures $\left(850-950^{\circ} \mathrm{C}\right)$ than the Roşia Montană samples which seem to have been fired at lower temperatures $\left(800-900^{\circ} \mathrm{C}\right)$.

Taking into account the matrix mineralogical composition (illite, kaolinite \pm smectite \pm calcite + micas + iron oxihydroxides), we presume that clays with similar composition and which occur west of Sântimbru, east of Şard and west of Alba Iulia, were used as raw material. These deposits are still mined for the bricks and tiles production.

The mineralogical and petrographical composition of crystalloclasts and lithoclasts respectively, both in the Roşia Montană and the Alba Iulia tegular samples is similar. We presume that the temper was most likely mined on the right bank of the Mureş river, south-east of Alba Iulia, based on the frequency of some lithoclasts, as granites-granodiorites (similar to those outcropping north of Alba Iulia in the hydrographic basin of the Arieş), as well as basalts, basaltic andesites, radiolarites (undoubtedly originated from the Mesozoic ophiolitic zone occurring west of Alba Iulia) and limestones (outcropping also west of Alba Iulia, together with ophiolites) both in the tegular ceramic samples and in the alluvial quartz sands of the Mureş river, downstream the junction with the Arieş river. Even nowadays this area offers sands used as temper materials for ceramics. 


\section{ACKNOWLEDGEMENTS}

Prof. Dr. Volker Hoeck (Salzburg University, Austria) is thanked for his careful revision and constructive comments which helped to improve the manuscript. Special thanks are due to Mrs. Tania Makarenco for the English review. This study was financially supported by the Romanian Ministry for Education and Reserch, under the Grant no. 1762.

GLOSSARY OF MINERALOGICALPETROGRAPHICAL - GEOLOGICAL TERMS USED IN THE PAPER (from Ionescu, Ghergari 2006 and references herein)

anisotropy. The property of the crystallized minerals to present variations of some physical (including optical) properties, function of direction. At polarizing microscope, under crossed nicols, the anisotropic minerals are light.

diffusion. Movement of ions, atoms or molecules in a gas, liquid or solid because of the concentration gradient (zones with different concentrations). E.g. the diffusion of $\mathrm{Fe}$ from the matrix towards the quartz clasts in the ceramics fired at high temperatures (over 900$\left.950^{\circ} \mathrm{C}\right)$

gehlenite. $\mathrm{Al}$ and $\mathrm{Ca}$ silicate which forms at the contact between calcitic calsts and the clayish matrix or in the matrix with calcite content, at temperatures over $850^{\circ} \mathrm{C}^{12}$.

granulometric analysis. Measuring the size of the particles.

heavy minerals. Minerals with high density, which accumulate in the sandy sediments of rivers, e.g. garnets, pyroxenes, amphiboles, zircon a.o.

hematite. Iron oxide $\left(\mathrm{Fe}_{2} \mathrm{O}_{3}\right)$. The redcolour of some fired ceramics is due to the presence of hematite. During the firing, oxihydroxides found in clays loses $\mathrm{OH}^{-}$and changes starting with $270^{\circ} \mathrm{C}$, into the so-called protohematite. The latter will lose the whole remnants of $\mathrm{OH}^{-}$around $800^{\circ} \mathrm{C}$, when it will transform into hematite ${ }^{13}$. In the ceramics,

\footnotetext{
${ }^{12}$ Antonelli et al. 2002; Kacim, Hajjaji 2003; personal experimental data, Grant 1762/2003-2005.

${ }^{13}$ Gualtieri, Venturelli 1999.
}

hematite is an indicator mineral for the oxidizing atmosphere and thermal conditions of firing.

illite. Clay mineral, main constituent of the clays, formed in nature by mica hydration. Illite is partly fusible and is used for ceramics production. Chemically, it is a $\mathrm{K}$ aluminisilicate with $\mathrm{OH}^{-}$content.

isotropic. Characteristic of some minerals which present constant vectorial physical properties in all directions. E.g. the light propagation through amorphous and cubic minerals (isotropic substances) takes place with the same speed in all directions. At the petrographic microscope (plane-polarized light), under crossed nicols, the isotropic minerals and substances appear dark.

kaolinite. Clay mineral, aluminosilicate with $\mathrm{OH}^{-}$content, very fine-grained. When pure, it has a white colour. Kaolinite represents the raw material for porcelain production and is the main constituent of the ceramic clays. In nature, it forms from some aluminosilicate minerals alteration.

microcrystalline-amorphous. Fabric of the sintered and partly vitrified clayish matrix in which some crystalline phases are still left (excepting the crystalloclasts and/or lithoclasts).

nicol. Perfect clear calcite prism used in the petrographical microscope to produce plane-polarized light.

occurrence. The place on the earth surface, where geological formations as rocks occur. Sin. Outcrop.

polarized light. Single-plane vibrating light. It is obtained after the normal light (vibrating in all directions) passes through a polarizing plate or a nicol.

polymictic clay. Clay rock composed from more than one single clay mineral species. E.g. illitic-kaolinitic clay, illitic-smectitic clay etc.

radiolarite. Siliceous rock, which contains skeleton remnants of marine pelagic organisms (Radiolaria sp.).

reaction rim. Area where some substance changes between two different minerals take place. Foe example, in ceramics reaction rims may occur at the very limit between the clayish matrix and some clasts. 
sintering. Physical, chemical and mineralogical process which alter the plastic clay mixture and transforms it into a rigid, nonplastic and cohesive body, during the firing. The sintering is expressed by the starting of softening-melting of the microparticules rims, which stuck and remained welded together after the cooling.

smectite. Clay mineral, main component of some clays. Smectites are $\mathrm{Al}, \mathrm{Mg}, \mathrm{Fe}$ silicates with $\mathrm{OH}^{-}$content and variable amounts of $\mathrm{Ca}$ and $\mathrm{H}_{2} \mathrm{O}$. They have high absorption capacity for water, which increases the volume. The presence of high amount of smectites in the ceramic mixture may cause large variations of volume during drying and firing, i.e. defects and even breakage. temper. Fine-grained material, nonplastic, present in the raw clay material (natural temper) or added by man in the ceramic mixture (artificial temper) to lower the plasticity of the paste down to the workability stage. The temper plays also an important role in the drying and firing processes by the diminishing of the shrinkage coeficient, by the hardening of the fired ceramic body, by increasing the thermal-shock resistence (Shepard 1976; Velde, Druc 1999).

wollastonit. Ca-silicate $\left(\mathrm{CaSiO}_{3}\right)$ which is thermo-indicative for the ceramics obtained from calcareous clays, fired at over $850^{\circ} \mathrm{C}$ (Kacim, Hajjaji 2003).

$X$-ray powder diffractometry. Physical method used for the crystallized phases (minerals) identification.

\section{REFERENCES}

Alburnus Maior I - Alburnus Maior I (ed. P. Damian), Bucharest 2003. (in Romanian).

Antonelli et al. 2002 - F. Antonelli, S. Cancelliere, L. Lazzarini. Minero-petrographic characterisation of historic bricks in the Arsenale, Venice. Journal of Cultural Heritage, 3, 59-64.

Bayliss et al. 1986 - P. Bayliss, D.C. Erd, M.E. Mrose, A.P. Sabina, D.E. Smith. Mineral Powder Diffraction File. Data book. International centre for diffraction data. Swarthmore, PA. 1396 p.

Bota et al. 2003 - E. Bota, O. Țentea, V. Voișian. Edificiul public din punctul Tomuș (E1). Alburnus Maior I, 433-446 = The Public Edifice of "Tomuş" Site (E 1). Alburnus Maior I (english version).

Bruhns, Fischer 2001 - P. Bruhns, R.X. Fischer. Phase reactions in the brick firing process of V-dopped clay. Eur. Journal Mineral., 13, 611-619.

Cairo et al. 2001 - A. Cairo, B. Messiga, M.P. Riccardi. Technological features of the „Cotto Variegato”: a petrological approach. Jour. of Cultural Heritage, 2, 133-142.

Cultrone et al. 2001 - G. Cultrone, C. Rodriguez-Navarro, E. Sebastian, O. Cazalla, M.J. De la Torre. Carbonate and silicate phase reactions during ceramic firing. Eur. Journal Mineral., 13, 621-634.

Cultrone et al. 2005 - G. Cultrone, E. Sebastián, M.J. De la Torre. Mineralogical and physical behaviour of solid bricks with additives. Construction \& Building Materials, 19, 39-48.

Duminuco et al. 1998 - P. Duminuco, B. Messiga, M.P. Riccardi. Firing process of natural clays. Some microtextures and related phase comopsitions. Thermochimica Acta, 321, 185-190.

Gary et al. 1977 - M. Gary, R. Jr. McAfee, C.L. Wolf (Eds.). Glossary of geology. American Geological Institute, Washington D.C., $4^{\text {th }}$ ed., 857 p.

Ghergari, Ionescu 2000 - L. Ghergari, C. Ionescu. Applications of the analytical mineralogical methods in archaeology (Aplicații ale metodelor mineralogice de analiză în arheologie). Banatica 15/I, 261-270. Reşița. (in Romanian).

Ghergari et al. 1999 - L. Ghergari, Gh. Lazarovici, C. Ionescu, T. Tămaş. Geoarchaeological studies on ceramic artefacts from Early Neolithic from Romania: Lunca-Poiana Slatinii, Neamt county (Studii geoarheologice asupra unor artefacte ceramice din Neoliticul timpuriu din România: Stațiunea de la Lunca-Poiana Slatinii, Jud. Neamț). Angustia 4, 1-7, Sf. Gheorghe (in Romanian).

Ghergari et al. 2000 - L. Ghergari, O. Țentea, F. Marcu. Mineralogical aspects of the hand-made ceramics from the Roman castrum of Gilău (Aspectele mineralogice ale ceramicii lucrate cu mâna din castrul roman de la Gilău). Apulum, 37/1, 401-416. (in Romanian). 
Gualtieri, Venturelli 1999 - A.F. Gualtieri, P. Venturelli. In situ study of goethite-hematite phase transformation by real time synchroton powdre diffraction. American Mineralogist 84, 895-904.

IDR III/6 - Inscripțiile Daciei Romane III. Apulum - Instrumentum domesticum (Cl.L. Băluță), Bucureşti, 1999.

Ionescu, Ghergari 2002 - C. Ionescu, L. Ghergari. Modeling and firing technology - reflected in the textural features and mineralogy of the ceramics from Neolithic sites in Transylvania (Romania). Geologica Carpathica 53, Sp. is. (CD).

Ionescu, Ghergari 2004 - C. Ionescu, L. Ghergari. Vinča ceramics (Middle Neolithic) in Transylvania: petrographical and geoarchaeological features. In Chatzipetros, A.A. \& Pavlides, S.B. (Eds.): The Proceedings of the $5^{\text {th }}$ International Symposium on Eastern Mediterranean Geology 2, 751-754. Thessaloniki (Greece).

Ionescu, Ghergari 2006 - C. Ionescu, L. Ghergari. Small glossary of geological terms used for ancient ceramics (Mic glosar de termeni geologici utilizați în studiul ceramicii arheologice). Cercetări Arheologice, 13 (this volum). (in Romanian).

Kacim, Hajjaji 2003 - S. Kacim, M. Hajjaji. Firing transformations of a carbonatic clay from the HighAtlas, Morocco. Clay Minerals 38, 361-365.

Maritan 2004 - L. Maritan. Archaeometric study of Etruscan-Padan type pottery from the Veneto region: petrographic, mineralogical and geochemical-physical characterisation. Eur. Journal Mineral., 16, 297-307.

Mihăilescu, Grigore 1981 - N.Şt. Mihăilescu, I. Grigore. Mineral resources for building materials in Romania (Resurse minerale pentru materiale de construcții în România). Edit. Tehnică Bucharest, 422 p. (in Romanian).

Pârvu et al. 1977 - G. Pârvu, Gh. Mocanu, C. Hibomvschi, A. Grecescu. Useful rocks from Romania (Roci utile din România). Editura Tehnică Bucharest, 408 p. (in Romanian).

Rapp, Hill 1998 - G.Jr. Rapp, C.G. Hill. Geoarchaeology. Yale Univ. Press, 274 p.

Riccardi et al. 1999 - M.P. Riccardi, B. Messiga, P. Duminuco. An approach to the dynamics of clay firing. Applied Clay Science 15, 393-409.

Shepard 1976 - A.O. Shepard. Ceramics for the archaeologist. Carnegie Institute, 414 p., Washington.

Țentea 2003 - O. T,entea, Legion XIII Gemina and Alburnus Maior. Apulum, 40, 253-265.

Țentea 2003a - O. T,entea, About the mineralogical methods in archaeology and their importance in historical writing (Despre utilizarea metodelor mineralogice în arheologie şi relevanţa lor în scrisul istoric). Cum scriem istoria? Apelul la ştiinţe şi dezvoltările metodologice contemporane. Actele simpozionului "Tinerii Istorici”, ediția a IV-a, Alba Iulia, 28-30 noiembrie 2002 (ed. R. Mârza, Laura Stanciu) Alba Iulia, 115-119. (in Romanian).

Țentea, Voişian 2003 - O. Țentea, V. Voişian. Edificiul public din punctul Bisericuță (E2]. Alburnus Maior I, 447-67 = The Public Edifice of "Bisericuță" (E 2). Alburnus Maior I (english version).

Velde, Druc 1999 - B. Velde, C.I. Druc. Archaeological ceramic materials. Origin and utilization. Springer-Verlag, 299 p., Berlin.

Voişian, Țentea 2004 - V. Voişian, O. Țentea. Alburnus Maior. Carpeni Hill - Bisericuță (Alburnus Maior. Dealul Carpeni - Bisericuță). Cronica Cercetărilor Arheologice din România. Campania 2003, Bucharest, 280-282. (in Romanian).

Wollmann 1996 - V. Wollmann. Metals and salt mining and stone quarries in Roman Dacia (Mineritul metalifer, extragerea sării şi carierele de piatră în Dacia romană (in Romanian and in German). Bibl. Mvsei Napocensis XIII, 469 p.

*** (1967) Geological Map of Romania, 1:200.000, Bistriţa Sheet, Inst. Geol. Geophys. Bucharest.

*** (1967) Geological Map of Romania, 1:200.000, Turda Sheet, Inst. Geol. Geophys. Bucharest.

*** (1968) Geological Map of Romania, 1:200.000, Orăştie Sheet, Inst. Geol. Geophys. Bucharest.

*** (1968) Geological Map of Romania, 1:200.000, Topliţa Sheet, Inst. Geol. Geophys. Bucharest.

\section{Corina Ionescu, Lucreția Ghergari}

Chair of Mineralogy, Babeş-Bolyai University,

1 Kogălniceanu str., RO-400084 Cluj-Napoca, Romania.

E-mail: corinai@bioge.ubbcluj.ro,ghergari@bioge.ubbcluj.ro.

\section{Ovidiu Țentea}

Romanian National History Museum, 12 Calea Victoriei, RO-030026 Bucharest, E-mail: ovidiu_tentea@yahoo.com,ovidiu@mnir.ro. 